\title{
SOEP
}

SOEPpapers

SOEPpapers
on Multidisciplinary Panel Data Research
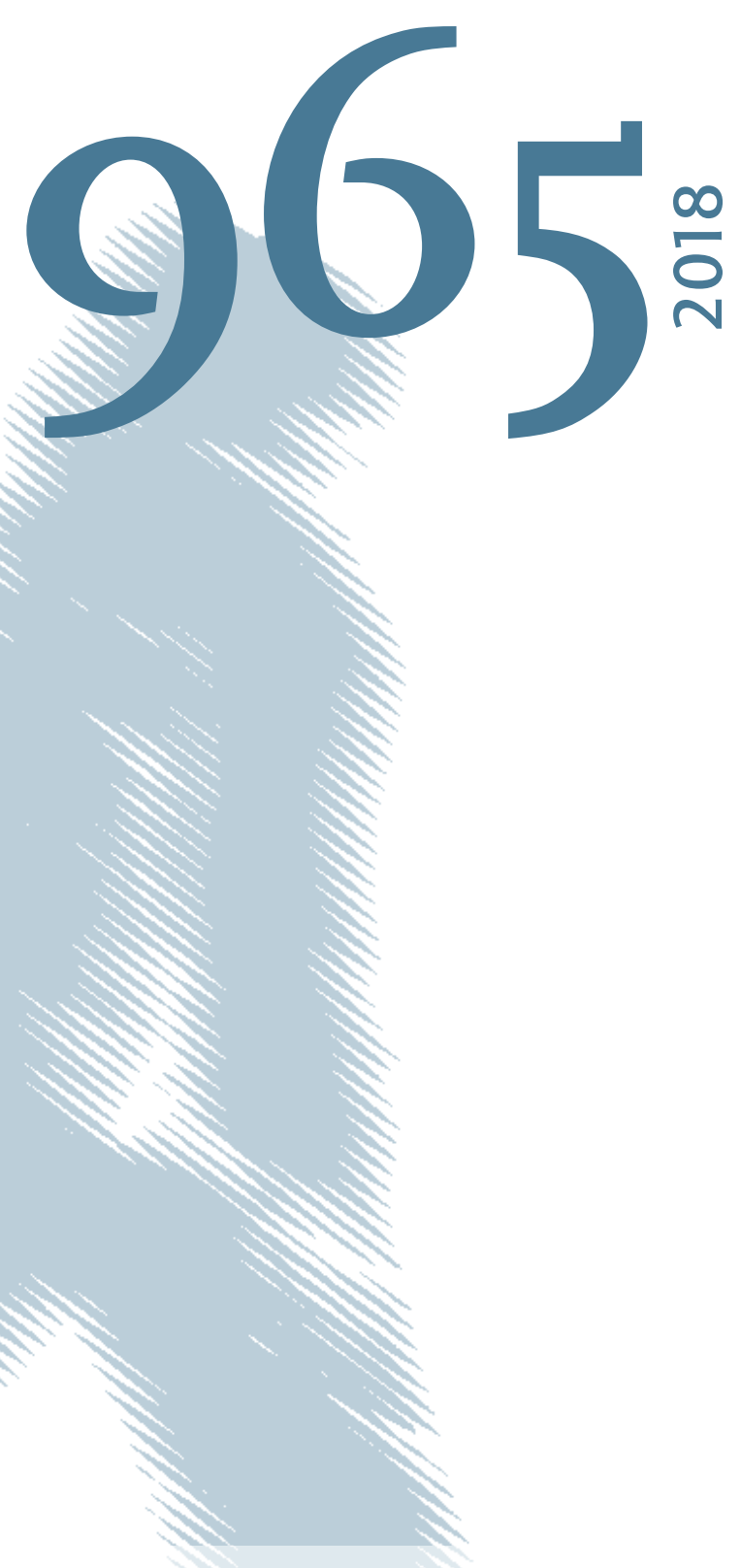

\section{Can Personality Traits Explain Glass Ceilings?}


This series presents research findings based either directly on data from the German SocioEconomic Panel study (SOEP) or using SOEP data as part of an internationally comparable data set (e.g. CNEF, ECHP, LIS, LWS, CHER/PACO). SOEP is a truly multidisciplinary household panel study covering a wide range of social and behavioral sciences: economics, sociology, psychology, survey methodology, econometrics and applied statistics, educational science, political science, public health, behavioral genetics, demography, geography, and sport science.

The decision to publish a submission in SOEPpapers is made by a board of editors chosen by the DIW Berlin to represent the wide range of disciplines covered by SOEP. There is no external referee process and papers are either accepted or rejected without revision. Papers appear in this series as works in progress and may also appear elsewhere. They often represent preliminary studies and are circulated to encourage discussion. Citation of such a paper should account for its provisional character. A revised version may be requested from the author directly.

Any opinions expressed in this series are those of the author(s) and not those of DIW Berlin. Research disseminated by DIW Berlin may include views on public policy issues, but the institute itself takes no institutional policy positions.

The SOEPpapers are available at http://www.diw.de/soeppapers

\section{Editors:}

Jan Goebel (Spatial Economics)

Stefan Liebig (Sociology)

David Richter (Psychology)

Carsten Schröder (Public Economics)

Jürgen Schupp (Sociology)

Conchita D'Ambrosio (Public Economics, DIW Research Fellow)

Denis Gerstorf (Psychology, DIW Research Fellow)

Elke Holst (Gender Studies, DIW Research Director)

Martin Kroh (Political Science, Survey Methodology)

Jörg-Peter Schräpler (Survey Methodology, DIW Research Fellow)

Thomas Siedler (Empirical Economics, DIW Research Fellow)

C. Katharina Spieß (Education and Family Economics)

Gert G. Wagner (Social Sciences)

ISSN: 1864-6689 (online)

German Socio-Economic Panel (SOEP)

DIW Berlin

Mohrenstrasse 58

10117 Berlin, Germany

Contact: soeppapers@diw.de

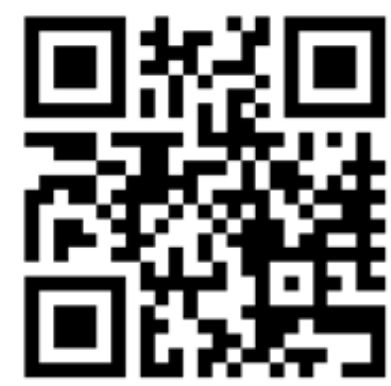




\title{
Can Personality Traits Explain Glass Ceilings?
}

\author{
Matthias Collischon ${ }^{\mathrm{a}}$ \\ ${ }^{a}$ Friedrich-Alexander University Erlangen-Nürnberg \\ Department of Economics, Lange Gasse 20, 90403 Nürnberg, Germany
}

\begin{abstract}
This paper investigates whether personality traits can explain glass ceilings (increasing gender wage gaps across the wage distribution). Using longitudinal survey data from Germany, the UK, and Australia, I combine unconditional quantile regressions with wage gap decompositions to identify the effect of personality traits on wage gaps. The results suggest that the impact of personality traits on wage gaps increases across the wage distribution in all countries. Personality traits explain up to $14.5 \%$ of the overall gender wage gap. However, controlling for personality traits does not lead to a significant reduction of unexplained wage gaps in most cases.
\end{abstract}

Keywords: non-cognitive skills, personality traits, unconditional quantile regression, gender wage gap, glass ceiling

JEL: C21, J16, J31

\footnotetext{
This research did not receive any specific grant from funding agencies in the public, commercial, or not-for-profit sectors. Conflicts of interest: none.

Email address: matthias. collischon@fau.de (Matthias Collischon)
} 


\section{Introduction}

Glass ceilings, i.e. gender wage gaps that increase across the wage distribution, are present in many countries (see for example Christofides et al., 2013). However, the causes of gender wage gaps in general and glass ceilings in particular, especially when they persist after accounting for (self-)selection into occupations and industries, are still puzzling. This paper investigates whether personality traits ${ }^{1}$ can explain glass ceilings in wages.

Several findings support the notion that personality traits could play a role in gender wage differentials: women tend to do worse in competitive, mixed-sex situations (Azmat et al., 2016; Booth and Yamamura, 2016), shy away from competitive pay schemes that generally pay more (Heinz et al., 2016; McGee et al., 2015; Niederle and Vesterlund, 2007), fare worse in wage negotiations (Stuhlmacher and Walters, 1999) and obtain lower bonus payments (e.g. performance premiums) than males (Card et al., 2016). Success in wage negotiations, risk aversion, and competitive behavior are likely manifestations of personality traits.

I investigate the connection between gender wage gaps and personality traits with data from the German Socio-economic Panel (SOEP), the United Kingdom Household Longitudinal Study (UKHLS) and the Household, Income and Labor Dynamics in Australia (HILDA) panel. The datasets survey the five factor model of personality (also known as the big five), locus of control (SOEP and HILDA only), positive and negative reciprocity (SOEP only) and risk taking (SOEP only). I combine unconditional quantile regressions (UQRs, Firpo et al., 2009) with a decomposition method proposed by Fortin (2008) to estimate the impact of personality traits on gender wage gaps at different points of the wage distribution.

I contribute to the literature in two ways. First, I estimate gender wage gaps across the unconditional wage distribution which provides new insights into the composition of wage differentials. Previous studies mostly rely on methods based on conditional quantile regressions (Christofides et al., 2013; Kee, 2006). Second, this is, to my knowledge, the first paper that investigates the role of

\footnotetext{
${ }^{1}$ For consistency, I solely use the term personality traits in this paper. I use personality traits synonymously with non-cognitive skills, a term often used in the literature.
} 
personality traits in explaining the glass ceiling effect for women and thus contributes to a more nuanced understanding of the connection between personality traits and gender wage gaps. I am interested if personality traits can be regarded as omitted variables that bias the estimation of gender wage gaps. However, I do not claim to identify causal effects of personality traits on wages because I cannot use truly exogenous variation in personality traits to estimate effects.

My findings indicate that personality traits have an increasing impact ${ }^{2}$ on gender gaps across the wage distribution in all countries and account for a maximum of around $14 \%$ of the overall gender gap. However, the impact of personality traits on unexplained gender wage gaps compared to a model with classical controls without controlling for personality traits is statistically insignificant in most cases. This suggests that the effect of personality traits on gender wage gaps is partly captured by other control variables like occupation. Thus, the impact of personality traits on wage gap estimations in terms of an omitted variable bias is modest in most cases.

This paper is organized as follows: Section 2 provides theoretical considerations and a literature review. Section 3 provides an overview over the data and personality traits used in the analysis. Section 4 presents the econometric methods used in the analysis. Section 5 shows and discusses the results and various robustness tests. Section 6 concludes.

\section{Theoretical Background \& Previous Findings}

\subsection{Gender discrimination \& Glass Ceilings}

Explanations for gender wage differentials often rely on discrimination theories (for an overview over various explanations see Blau and Kahn, 2017). Taste-based discrimination Becker (1971) is a classical explanation for gender wage differentials. Becker (1971) argues that employers discriminate against females through wages if male employees prefer working with males and thus demand a premium for working with females. Additionally, employers themselves could exhibit a taste for discrimination and thus discriminate against women in terms of wages or employment. The pollution theory of discrimination (Goldin, 2014) argues, comparably, that males want to prevent

\footnotetext{
${ }^{2}$ For readability, I sometimes use the word "effect" or "impact" even if solely referring to a partial correlation.
} 
females from "polluting" the status of their occupation by introducing female values. Thus, males demand compensations for working with females. Comparable sociological theories (e.g. Ridgeway, 2001) argue that gender stereotypes incorporate status beliefs and that males are regarded as more competent. This belief justifies gender wage differentials.

These theories predict discrimination against females even when holding productivity constant. Arguably, this is not always the case. While empirical studies typically account for differences in schooling, labor market experience, etc., there may be other factors that affect productivity and differ systematically between genders, such as personality traits. Traits like conscientiousness or extraversion likely affect productivity, especially in high-paying positions. For example, extraversion can be beneficial for managers to motivate employees or attract customers and thus affect productivity. Potentially, men exhibit on average higher degrees of these traits.

Additionally, personality traits could be used as criteria for discrimination that reflect gender discrimination. Taste-based discrimination does not necessarily imply that males prefer to work with males in contrast to females or that employers prefer males over females just because of gender. Taste-based discrimination can also mean that males and male employers want to work with individuals with similar personalities and discriminate based on these. For example, extraverts could want to work with extraverts. If there are systematic gender differences in personality traits, males would favor to work with males and thus discriminate against females, e.g. if males are on average more extravert.

In both cases, personality traits as productivity-relevant characteristics and as criteria for discrimination, personality traits can be regarded as omitted variables that bias the estimation of discriminatory gender gaps ${ }^{3}$ if they are not included in the model. Thus, in a first step, investigating whether personality traits are linked to wages, either directly (e.g. if they relate to productivity) or indirectly (e.g. through access to certain highly-paid occupations) is important. In a second step, it is important to investigate whether there are really systematic gender differences in certain personality

\footnotetext{
${ }^{3}$ Discrimination based on personality traits would also imply wage differentials that are not based on productivity. However, distinguishing between the two mechanisms is nevertheless important because discrimination based on gender may lead to different policy implications compared to discrimination based on personality.
} 
traits. If both conditions are satisfied, not controlling for personality traits would lead to an omitted variable bias in wage gap estimations.

A large body of empirical evidence finds significant gender wage differentials in most countries that largely cannot be explained by gender differences in human capital endowments or even differences in occupational choice (e.g. Blau and Kahn, 2017; Finke, 2010). Recent studies (e.g. Arulampalam et al., 2007; Christofides et al., 2013; Collischon, 2017a) also report glass ceilings in various countries. However, these studies could be subject to the omitted variable bias described previously, because they do not control for personality traits. Thus, further investigating the connection between gender, personality and wages is important.

\subsection{Personality \& wages}

Bowles et al. (2001) develop a framework in which personality traits influence how strongly individuals react to incentives. They argue that personality traits affect the costs of eliciting effort. Thus, ceteris paribus, individuals with specific personality traits that lower these (mental) costs are more productive than their counterparts with unfavorable personality traits and therefore receive higher wages.

A number of studies investigates the connection between personality and wages. The most influential studies come from Mueller and Plug (2006) for the US, Heineck and Anger (2010) for Germany, Heineck (2011) for the UK and Nyhus and Pons (2005) for the Netherlands. The findings consistently show that personality traits significantly affect earnings. However, these studies solely investigate effects of personality traits at the mean.

Collischon (2017b) further expands theoretically on the connection between personality traits and wages. He argues that personality traits should have a more pronounced connection to wages for high-wage employees, where individual wage bargaining and productivity pay are more important compared to their low-wage counterparts. For low-wage employees in contrast, wages are largely determined by law through minimum wages or collective agreements and thus do not leave much room for further discrimination. Empirical analyses using UQR for Germany, the UK and Australia support the notion. His findings indicate that risk taking, neuroticism and agreeableness have a 
stronger connection to wages for high- compared to low-wage employees (Collischon, 2017b).

\subsection{Gender \& Personality}

As previously discussed, personality traits significantly affect wages. However, to significantly affect gender wage gaps, there have to be differences in endowments and/or returns to certain personality traits between men and women. Previous research finds differences in endowments with certain personality traits. Bouchard and Loehlin (2001) and Schmitt et al. (2008) find that females exhibit higher scores in neuroticism and agreeableness. Semykina and Linz (2007) report that women have a more external locus of control. These traits are typically negatively related to wages (e.g. Heineck and Anger, 2010).

Additionally, there is evidence on gender differences in selection into competitive payment schemes (e.g. Niederle and Vesterlund, 2007), competitive behavior (e.g. in mixed-sex tournaments Booth and Yamamura, 2016) and wage negotiations (Stuhlmacher and Walters, 1999) that all seems to disadvantage females and that could also be driven by differences in personality traits. Thus, systematic differences in personality traits can potentially explain gender wage gaps.

The literature also suggests that the returns to certain personality traits differ between men and women. Mueller and Plug (2006) find that conscientiousness has a positive wage effect for females, but the connection not for males. Agreeableness in return affects males' wages, but has no significant effect on females' wages. Heineck and Anger (2010) find positive effects of openness to experience on wages for females, but negative effects for males. Additionally, they report positive effects of extraversion and conscientiousness for males only. Other studies (Heineck, 2011; Nyhus and Pons, 2005) also show gender differences in returns to personality traits. Thus, differences in returns to certain traits could contribute to gender wage gaps.

Overall, the literature on personality traits and wages suggests differences in endowments as well as in returns to personality traits between men and women that could potentially affect gender wage gaps. Some studies link personality traits to gender wage gaps. Mueller and Plug (2006) run an Oaxaca-Blinder decomposition and find that the big five account for $3 \%$ of the gender wage gap conditional on other covariates. Fortin (2008) finds that self-esteem, locus of control and two other 
traits explain around $10 \%$ of the overall gender wage gap. Nyhus and Pons (2012) find that the big five, locus of control and time preference on wage gaps account for $12.5 \%$ of the overall gender wage gap in the Netherlands. Braakmann (2009) investigates the connection between gender wage gaps and the big five, locus of control, reciprocity and risk taking with data from Germany. His estimations indicate that personality traits explain $4.9 \%$ to $13.6 \%$ of the overall gender wage gap, dependent on the reference wage structure. Semykina and Linz (2007) find that locus of control and need for challenge or affiliation explain $8 \%$ of the gender wage gap. ${ }^{4}$

\subsection{Expectations}

Theoretical considerations suggest that personality traits are omitted variables that bias gender wage gap estimations if personality traits (i) differ systematically between men and women and (ii) are significantly related to wages. Previous empirical studies support both notions and show that personality traits do indeed lead to a modest reduction of gender wage gaps at the mean. However, to my knowledge, no study investigates if personality traits explain glass ceilings, even if theoretical considerations as well as empirical findings suggest that both the connection between personality traits and wages and therefore the connection between personality traits and gender wage gaps increase across the wage distribution. Thus, personality traits are likely to affect glass ceilings in wages.

Based on previous findings, I expect that including personality traits in gender wage gap estimations (i) overall leads to a reduction of unexplained gender gaps and (ii) to have an especially pronounced impact on glass ceilings. I test these expectations with survey data from various countries to (i) investigate the generalizability of my results and (ii) to investigate if different measures for certain traits (for example different scales for the big five) affect the results.

\footnotetext{
${ }^{4}$ Blau and Kahn 2017 provide a detailed overview over the literature in section 4 of their article.
} 


\section{Data \& Measures of Personality}

\subsection{Estimation Samples}

I use three datasets in my analysis: the German Socio-Economics Panel (SOEP, Wagner and Frick, 2007) from 1991 to 2015, the UK's Understanding Society (UKHLS) from 2009 to 2015 and the Household, Income and Labour Dynamics in Australia (HILDA, Wooden and Watson, 2007) survey from 2001 to 2015. All data contain information on the respondent's age (and age squared), schooling, marital status, whether a child under the age of 16 (SOEP \& UKHLS) resp. 15 (HILDA) is part of the household, establishment size, full-time employment, occupation (2-digits), industry (major groups) ${ }^{5}$ and survey year (dummy variables) which serve as control variables. I additionally control for a dummy variable for living in East Germany in the SOEP. The dependent variable is the natural logarithm of hourly wages. All samples are restricted to part- and full-time working employees aged 19 to 65 . Overall, the German sample consists of 152,777 observations for 20,008 individuals, the British sample consists of 68,614 observations for 17,169 individuals and the Australian sample consists of 49,514 observations for 10,007 individuals. ${ }^{6}$

The datasets also contain additional information on relevant variables like tenure or labor market experience and the samples are also restricted to individuals with vaild information in these variables. ${ }^{7}$ However, the amount of these additional controls and their respective measurements vary between the data sets. To ensure comparability of the results, I only use the previously described controls in my main analysis. Additionally, I run regressions that make full use of the information available in the data in the robustness section to see if adding controls changes the results substantially.

\footnotetext{
${ }^{5}$ Occupation and industry can be regarded as bad controls. I further discuss this topic when presenting my empirical specification.

${ }^{6}$ Tables A1 to A3 provide summary statistics for controls in the data.

${ }^{7}$ For comparability with the main results. However, the results do not change significantly when dropping this restriction.
} 


\subsection{Personality Traits in the Data}

The datasets also include measures of various personality traits. The five factor model (McCrae and Costa, 2008) distinguishes five basic personality traits: extraversion, agreeableness, conscientiousness, neuroticism and openness to experience. Extraversion is related to social orientation. Agreeableness captures cooperative behavior. Conscientiousness measures planned (in contrast to spontaneous) behavior and neuroticism (sometimes refered to as emotional stability) relates to anxiety and being moody (Judge et al., 1999). These traits are likely to correlate with behavior in wage negotiations. For example, agreeable individuals could performs worse in wage bargainings than their more aggressive counterparts. Additionally, traits like conscientiousness could for example lead to fewer mistakes in certain tasks and thus affect productivity. Thus, if men and women differ in these traits, this could contribute to gender wage gaps. The SOEP and the UKHLS survey the big five with 15 items (with 3 question for each trait, Dehne and Schupp, 2007), HILDA uses a more sophisticated scale that consists of 40 items of which I use 28 in my analysis, in line with Losoncz (2009).

External Locus of control refers to degree of perceived control over the events in one's life (Rotter, 1966). Individuals that score high on this scale are more likely to believe that they their lives are rather determined by chance than by their own actions. Having a high external locus of control should thus be related to lower wages. While the SOEP and HILDA survey locus of control with 8 resp. 7 items, the UKHLS contains no measure for locus of control.

The SOEP additionally surveys positive and negative reciprocity with 3 items each, and risk taking behavior on a self-rated 11-point-scale, which are also related to wages (Collischon, 2017b) and could differ systematically between men and women. In line with previous studies (Collischon, 2017b; Heineck and Anger, 2010), I construct additive indices for each trait. ${ }^{8}$ Because not every survey wave contains all items, I follow the imputation method suggested by Heineck and Anger (2010). Gaps due to missing questions in the survey are filled by imputing the previous or next (whichever is closer to the survey year) valid response. Additionally, I regress the respective

\footnotetext{
${ }^{8}$ Collischon (2017b) provides detailed overview over the items in the respective datasets.
} 
personality items on age and age squared because personality traits are largely stable, but can change with age (Cobb-Clark and Schurer, 2012). I use the residuals from these regressions as measures of personality traits that are cleared of age effects and standardize all scales by dividing the respective traits by their sample specific standard deviation.

Personality traits would be "bad" explanatory variables if they are themselves endogenous. For example, women could experience discrimination in the labor market which in turn leads to changes in their personality traits. However, previous studies show that personality traits are fairly stable (Elkins et al., 2017) and that changes in personality traits are hardly related to labor market events (Anger et al., 2017; Cobb-Clark and Schurer, 2013).

Table 1 shows the means of the personality items by gender. In nearly all cases, except for locus of controls and neuroticism in Australia, the gender differences are highly significant. Generally, men exhibit characteristics that could be positively related to wages, like lower degrees of external locus of control, neuroticism, agreeableness, and a higher degree of risk taking. This indicates that personality traits could be a reason for gender wage gaps.

\section{Econometric Method}

\subsection{Unconditional Quantile Regression}

The UQR essentially performs an OLS-regression on the recentered influence function (RIF) of a statistic of interest of a dependent variable $Y$ (in the case of this paper: the natural logarithm of the hourly wage). Influence functions are used to asses the marginal impact of particular observations on a statistic of interest. In this paper, I use the RIF-concept to investigate specific quantiles in this context. The influence function of a quantile $\tau$ can be written as:

$$
\operatorname{IF}\left(Y, Q_{\tau}\right)=\frac{\tau-\mathbb{1}\left\{Y \leq Q_{\tau}\right\}}{f_{y}\left(Q_{\tau}\right)}
$$

where $\mathbb{1}\left\{Y \leq Q_{\tau}\right\}$ is an indicator function to weight the quantile, $f_{y}$ is the density function of the marginal distribution at $Q_{\tau}$. The RIF-concept extends this approach by adding the quantile of choice $Q_{\tau}$ to the influence function: 


$$
R I F\left(Y, Q_{\tau}\right)=Q_{\tau}+\frac{\tau-\mathbb{1}\left\{Y \leq Q_{\tau}\right\}}{f_{y}\left(Q_{\tau}\right)}
$$

The RIF is then used is the dependent variable in an OLS-regression. UQR estimates marginal effects of regressors on a quantile $\tau$ of interest while OLS estimates marginal effects of regressors at the mean. In contrast to classical (conditional) quantile regression (CQR, Koenker and Bassett, 1978) which is based on conditional quantiles, UQR uses the unconditional distribution of $y$, independent of covariates included in the regression model. Thus, while the definitions of low- and high-wage employees in a CQR-framework depend on the covariates included in the estimation, UQR estimates marginal effects of covariates at unconditional quantiles of the wage distribution. Therefore, investigating glass ceilings in terms of overall low- and high-wage employees requires using UQR-methods.

\subsection{Decomposition of wage differentials}

I combine UQR with an Oaxaca-Blinder (OB; Blinder, 1973; Oaxaca, 1973) style decomposition. Instead of a decomposition at the mean, I run decompositions on the unconditional quantiles of interest obtained from UQR. In the classical OB-decomposition, the wage gaps depend on the choice of the reference group (which can drastically alter the results, e.g. Braakmann 2009). Neumark (1988) and Oaxaca and Ransom (1994) provide solutions to this issue by proposing a method that additionally uses a pooled regression without a gender dummy to obtain wage gaps that are independent of the reference wage structure. Their methods are widely used in the literature (e.g. Christofides et al., 2013; Semykina and Linz, 2007). However, this method is likely to underestimate unexplained wage gaps, because coefficients in the pooled estimation could capture gender differences due to omission of a gender indicator in the estimation (Elder et al., 2010; Fortin, 2008).

To account for this problem, I use the pooled decomposition proposed by Fortin (2008) in my analysis to decompose gender wage gaps at specific quantiles of interest (Fortin et al., 2011; henceforth called FFL-decomposition). This method obtains the unexplained wage gap from a 
pooled regression with a group indicator variable and uses the coefficient of this dummy variable as a measure for the unexplained wage gap and thus circumvents the problems of the Oaxaca and Ransom (1994) decomposition. ${ }^{9}$

The case of a wage decomposition at the mean (with the natural logarithm of wages $(\ln w)$ as the outcome of interest) with males as the omitted group in the pooled regression can be written as:

$$
\overline{l n w_{m}}-\overline{\ln w_{f}}=\Delta X \hat{\beta}_{p}+\left[\bar{X}_{m}\left(\hat{\beta}_{m}-\hat{\beta}_{p}\right)+\left(\hat{\beta}_{0 m}-\hat{\beta}_{0 p}\right)\right]-\left[\bar{X}_{f}\left(\hat{\beta}_{f}-\hat{\beta}_{p}\right)+\left(\hat{\beta}_{0 f}-\hat{\beta}_{0 p}\right)\right]
$$

where $\hat{\beta}$ are the estimated coefficients and $\hat{\beta}_{0}$ are the constants from pooled $(p)$ and genderspecific ( $m$ and $f$ ) regressions. $X$ is a set of regressors. $\Delta X \hat{\beta}_{p}$ is the difference in explained characteristics. The terms in brackets are used to assign proportions of the unexplained gap to variables in $X$. The decomposition can easily be extended to any statistic of the dependent variable of interest by using the respective RIF as the outcome of interest.

In the analysis, I estimate decompositions at the mean, median, 10th and 90th percentile to see whether personality traits can explain gender wage gaps for low-, high- and average-paid employees. The choice of these points in the wage distribution is arbitrary, but using other points of the distribution (e.g. the 25 th or 75 th percentile) does not change the overall findings in terms of the importance of personality traits for gender wage gaps.

I estimate several models to test the mechanisms at work. I start with a model that does not account for sorting into occupations and industries, because selection into specific jobs could also be an outcome of personality traits that is directly related to wages and is determined contemporaneously. In this sense, industry and occupation would be bad controls.

Nevertheless, the theoretical considerations also imply that gender differences in personality traits could directly affect wages, if personality traits affect productivity and wage bargaining directly. Additionally, not controlling for occupation and industry could also lead to an overestimation of

\footnotetext{
${ }^{9}$ Fortin et al. (2011) provide a comprehensive overview over various decomposition methods for further reading.
} 
gender wage gaps in terms of discrimination, if self-selection of women into specific occupations and not discrimination drives occupational segregation and consequently gender wage gaps. Furthermore, most studies that investigate gender wage gaps control for at least a small set of occupation and industry controls (e.g. Arulampalam et al., 2007). Thus, my baseline models accounts for occupation and industry to estimate the direct impact of personality traits on gender wage gaps net of sorting effects.

The decomposition method allows for a detailed decomposition of wage differentials thus showing how certain variables contribute to the explained and unexplained wage gaps. Thus, assessing the contribution of personality traits to gender wage differentials is possible. However, the impact of personality traits on wage gaps derived from the detailed decomposition is not necessarily equal to the overall change in unexplained wage gaps because other control variables (e.g. occupation) may party implicitly control for the effect of personality traits if they are correlated. Because I argue that personality traits represent an omitted variable bias in previous studies, I test statistical significance of the impact of personality traits on wage gaps by comparing the unexplained wage gaps obtained from decompositions with and without controlling for personality traits.

\section{Results}

\subsection{Main Results}

In this section, I show and discuss the results of the decomposition analyses. Table 2 displays the results of the FFL-decompositions without controlling for industry and occupation. This way, the estimations should capture the full effect of personality traits on gender gaps, because occupations and industries are closely related to wages and access to occupations and industries could as well be restricted due to discrimination based on personality traits. Table 2, panel A shows the results of the estimations without controlling for personality traits. Glass ceilings are present in all three countries, which is consistent with previous findings for the countries (Christofides et al., 2013; Collischon, 2017a; Kee, 2006).

Panel B of Table 2 adds personality traits to the estimations. Overall, unexplained gender wage 
gaps stay constant or increase in all estimations through the addition of personality traits, as expected. However, the differences between the unexplained gaps with and without controlling for personality traits are small in most cases with the exception of Germany: the gender wage gaps at the mean and at the 90th percentile of wages decrease significantly due to the addition of personality traits thus supporting the expectations derived from theory for Germany.

Overall, personality traits explain up to $13.7 \%^{10}$ of the overall gender wage at the points investigated (in this case at the 90th percentile of wages in the UK) while personality traits explain around $11-12 \%$ at the 90th percentile in Germany and Australia. Nevertheless, the impact of personality traits on unexplained gender gaps is statistically insignificant in all cases in the UK and Australia in terms of a significant reduction of the unexplained wage gap. However, it is hardly surprising that the impact of personality traits in the estimations (in terms of a significant reduction of the unexplained gap) is strongest in the German sample, given that this sample contains more measures of personality traits and a larger number of observations than the other samples. The findings concerning the mean wage gaps in this specification are comparable to previous findings by Braakmann (2009), Mueller and Plug (2006) and Semykina and Linz (2007) who find that personality traits explain between $3 \%$ to $13.6 \%$ of the overall gender wage gap. Nevertheless, the impact of personality traits on wages seems to increase slightly across the wage distribution.

Investigating if personality traits contribute to gender wage gaps in terms of endowments or systematically different returns can be insightful. The results (displayed in the lower part of Table 2) show that the differences in unexplained gender gaps is mostly driven by differences in endowments. Conditional on covariates, especially agreeableness, neuroticism, locus of control (in the SOEP) and risk taking, personality traits that are typically punished in terms of wages, seem to contribute to the gender wage gap due to more favorable endowments of men, mostly in line with findings from Braakmann (2009) and Nyhus and Pons (2012). Differences in coefficients seem to contribute to gender wage gaps in some cases (locus of control in Germany and Australia, neuroticism in

\footnotetext{
${ }^{10}$ I compute the share of personality traits on wages by summarizing the contribution of these traits to explained and unexplained gaps and dividing the result by the raw wage gap.
} 
the UK), but their overall contribution to unexplained gaps seems minor compared to effect of differences in endowments, which is comparable to the findings of Nyhus and Pons (2012) who find that differences in returns account for only $0.38 \%$ of the raw earnings differential between men and women. Figure 1 plots the decomposition results with the contribution of personality traits to explained and unexplained gaps and shows that personality traits hardly contribute to explained or unexplained gaps in any case.

Next, I account for sorting mechanisms and allocative discrimination and solely investigate the direct impact of personality traits on wage differentials within industries and occupations, which is my preferred specification because it solely captures direct wage effects of personality traits. Table 3 displays the results of the FFL-decompositions controlling for occupation and industry. Panel A shows the results without accounting for personality traits. Overall, controlling for occupation and industry leads to a modest decline in the unexplained gender wage gaps at all points investigated in all countries.

Panel B of Table 3 shows the results conditional on personality traits (Tables A4 to A7 show the regressions by gender and for the pooled samples used in the decomposition for each country). Personality traits still explain a small share of the gender wage gap, as shown in the detailed decomposition. The overall reduction in gender wage gaps is smaller, but still comparable to the estimations without accounting for sorting mechanisms. However, the differences between the unexplained gaps with and without controlling for personality traits are no longer statistically significant and the contribution of personality traits to wage gaps decreases to a maximum of $11.3 \%$ (90th percentile in the UKHLS). This indicates that personality traits partly contribute to gender gaps through sorting into certain occupations and industries.

Figure 2 shows the decomposition results across the wage distribution for all countries, including controls for industry and occupation. Overall, the graphs show that differences in returns to certain traits (the contributions to unexplained wage differentials) do hardly contribute to gender wage gaps in any case. However, the share of gender gaps explained by personality traits is minor in all cases. Even if the importance of personality traits in explaining gender wage gaps increases across the 
wage distribution, their contribution is nevertheless relatively small.

\subsection{Accounting for Sample Selection}

Personality traits could not only affect productivity and the probability to work in certain occupations, but also the decision to work at all. In this case, analyses with data just for the working population might suffer from sample selection bias. Potential solutions to this problem are using the Heckman (1979) approach to account for sample selection or setting the wages of non-working individuals to 0 instead of missing values. However, finding truly exogenous instruments for the Heckman approach is difficult and assuming that the potential wage rate of non-working individuals is indeed 0 is hardly realistic. I propose using the means of the wages in the prior and subsequent years around the missing value as the potential wage rate if the individual worked. This way, I should at least considerably reduce biases through dropping out of the labor force due to relatively low wages.

I impute missing wage information with the mean wages from the previous and consecutive two years. If these are not fully observed for the respective individuals, I use just the previous and consecutive year. If these are also missing, I use the consecutive or previous year to impute the hourly wage rate. I then correct wages by the consumer price indices obtained from the World Bank ${ }^{11}$ in all countries. I use the natural logarithm of the hourly wages obtained this way as dependent variables in the estimation. I solely control for education, age, age squared, marriage, children in the household and survey year dummies. Thus, with this minimal set of controls that is available for all individuals and the correction for sample selection, the estimations should yield an upper bound for the overall impact of personality on gender wage gaps.

Table 4 and Figure 3 show the results. Overall the differences between the estimations with and without accounting for selection are modest. However, this is hardly surprising because all three countries exhibit relatively high female labor force participation rates (Thévenon, 2013). Even when accounting for sample selection and just a minimal set of controls, personality traits explain no more

\footnotetext{
${ }^{11}$ Obtained from: https://data. worldbank. org/indicator/FP. CPI. TOTL.
} 
than a maximum of $14.5 \%$ of the gender wage gap (in this case at the 90th percentile in the UK), even if the difference between the unexplained wage gaps is statistically significant in this case.

Overall, the results show that personality traits seem to play a relatively minor role in explaining wage differentials. Nevertheless, the impact of personality traits on wage gaps seems to increase across the wage distribution. Figure 4 shows the relative share of wage gaps explained by personality traits for the specifications discussed previously. In all cases, except in the Australian sample in (a) and (b), the impact of personality traits on wage gaps increases across the wage distribution.

\subsection{Robustness Tests}

I run various checks to test the robustness of the findings. The results are reported in Table 5. All estimations include the full set of controls as well as occupation and industry indicators. In the robustness checks, I solely report unexplained gender wage gaps with and without accounting for personality traits to investigate if personality traits are omitted variables in these cases. First, I added survey-specific controls that are not equally available in all datasets to check if additional controls change the results (Table 5, Panel A). I added employment experience (full time, part time, unemployment) and tenure measured in years and migration status in the SOEP. The UKHLS contains additional information on overtime work. HILDA contains additional controls for migration status, casual employment, unemployment experience and tenure measured in years. Adding these controls only leads to a further decline of the gender wage gap. Personality traits still do not significantly reduce the unexplained gender wage gap.

Second, because personality traits can change with age (Costa and McCrae, 1994), I restricted the estimation samples to individuals aged 30 to 55 (Table 5, Panel B) to decrease the potential remaining problem of reverse causality. Nevertheless, personality traits do not significantly reduce wage gaps in this sample.

Third, personality traits could have more pronounced connections to wages for full time employees (Table 5, Panel C). Potentially, employers are better informed about the personalities of their employees if they work full time and are thus able to reward or punish certain traits. In contrast to the UK and Australia, the findings for full time employees in Germany now show a U-shaped pattern 
of the wage differential across the wage distribution, which is consistent with previous findings for full time employees (Huffman et al., 2016). However, even if the difference between the unexplained gaps with and without controlling for personality traits is now statistically significant in one case (the mean in Germany), the differences are still small and insignificant in the other cases.

Fourth, I use the Heckman (1979) approach as an alternative way to tackle sample selection (Table 5, Panel D). I use parental education (as a dummy variable indicating if mother and/or father have obtained a college degree) as the instrument for selection into the labor market, in line with the literature (Heineck and Anger, 2010). I additionally control for gender, survey year, marital status, the existence of a child in the household, age and age squared in the selection term. The estimations show that not taking sample selection into account leads to a downward bias of the wage gap, especially at the top of the wage distribution in most cases, while the unexplained gaps at the 10th percentile decline in most cases. However, this does not change the main findings. Controlling for personality traits does not lead to a significant reduction of unexplained gender wage gaps. Furthermore, it is questionable whether parental education is truly an exogenous instrument for labor market participation.

Another concern is that, because I use pooled data spanning over multiple years, gender wage gaps could vary over time. In this case, the pooled estimations would only show a distorted picture of the gender wage gaps. However, the gender wage gaps did not change significantly in neither Germany, the UK nor in Australia over the periods investigated.

\section{Conclusion}

This article investigates the connection between the glass ceiling in wages and personality traits in Germany, the UK, and Australia. In contrast to previous studies, I investigate gender wage differentials along the unconditional wage distribution, which provides a more intuitive definition of high- and low-wage employes than wage differentials in conditional distributions. Against expectations, analyses show that controlling for personality traits does not lead to a significant reduction of unexplained gender wage gaps in most cases. The maximum share of the gender wage 
gap explained by personality traits amounts to $14.5 \%$ at the 90 th percentile of wages in the UK and between $7 \%$ and $9 \%$ at the mean in all countries with a minimum set of control variables and when accounting for selection into the labor market.

This finding even reduces to a maximum of $11.3 \%$ (at the 90 th percentile in the UK) and $4 \%$ to $6 \%$ of the overall gender wage gap at the mean in all countries when accounting for occupation and industry, which is in line with the results from Mueller and Plug (2006). Thus, while this study provides evidence that personality traits work explain a small share of the gender wage gap in most countries and that the impact of non-cognitive skills on gender wage gaps increases across the wage distribution, the reduction in unexplained gender wage gaps is statistically insignificant in most cases. This finding can partly be explained because effects of personality traits are captured by other variables like occupation in classical wage gap estimations. Nevertheless, even when accounting for personality traits, human capital variables and occupation and industry, a large share of overall gender gaps remains unexplained and increases across the wage distribution.

This study has several limitations that could be adressed in future research. First, possibly, the personality traits analyzed in this study do not capture all relevant differences in personality traits between men and women. For example, preferences regarding labor market attitudes could be relevant for wages and are not necessarily captured by the scales used in the analysis. Second, because the wage measures are solely based on self-reported information, there could be systematic differences due to measurement error between the genders, e.g. if males tend to overestimate either their wages or working hours. Linking administrative information on wages and working hours to individual data containing personality traits would be a solution for this problem, but is hardly possible at the moment.

Even after controlling for personality traits, human capital characteristics, children, marriage and selection into occupations and industries, the results still show significant mean wage gaps and glass ceilings for women in all countries. What actually drives these gaps remains open for discussion. Discrimination along the job ladder (Lazear and Rosen, 1990) could be an explanation, but should largely be ruled out by controlling for occupation and industry. In the same manner, discrimination 
in the sense of the pollution theory (Goldin, 2014) should partly be ruled out by control variables like industry and occupation. Taste-based discrimination (Becker, 1971) and sociological theories of gender stereotypes (Ridgeway, 2001) remain plausible explanations for gender wage differentials .

\section{Acknowledgments}

The author would like to thank Silke Anger, Andreas Eberl, Sabrina Genz, Erik Plug, Malte Reichelt, Regina T. Riphahn, the participants of the 23th BGPE Workshop in Würzburg, the participants of the 7IKSWD conference in Berlin and the participants of Session E12 of the 29th EALE conference in St. Gallen for their helpful comments. This article uses unit record data from the Household, Income and Labour Dynamics in Australia (HILDA) Survey, which is a project initiated and funded by the Australian Government Department of Families, Housing, Community Services and Indigenous Affairs (FaHCSIA) and is managed by the Melbourne Institute of Applied Economic and Social Research. The findings and views reported in this article, however, are those

of the author and should not be attributed to either FaHCSIA or the Melbourne Institute. 


\section{References}

Anger, S., Camehl, G., Peter, F., 2017. Involuntary job loss and changes in personality traits. Journal of Economic Psychology 60, 71-91. doi:10.1016/j . joep.2017.01.007.

Arulampalam, W., Booth, A.L., Bryan, M.L., 2007. Is there a glass ceiling over Europe? Exploring the gender pay gap across the wage distribution. Industrial and Labor Relations Review 60, $163-186$.

Azmat, G., Calsamiglia, C., Iriberri, N., 2016. Gender Differences in Response to Big Stakes. Journal of the European Economic Association 14, 1372-1400. doi:10.1111/jeea.12180.

Becker, G.S., 1971. The Economics of Discrimination. Economics research studies of the Economics Research Center of the University of Chicago. 2. ed., 6 ed., Univ. of Chicago Press, Chicago.

Blau, F.D., Kahn, L.M., 2017. The gender wage gap: Extent, trends, and explanations. Journal of Economic Literature 55, 789-865. doi:10.1257/jel.20160995.

Blinder, A.S., 1973. Wage discrimination: reduced form and structural estimates. Journal of Human Resources 8, 436-455. doi:10.2307/144855.

Booth, A.L., Yamamura, E., 2016. Performance in Mixed-sex and Single-sex Tournaments: What We Can Learn from Speedboat Races in Japan. CEPR Discussion Paper 11685 .

Bouchard, T.J., Loehlin, J.C., 2001. Genes, evolution, and personality. Behavior Genetics 31, 243-273. doi:10.1023/A:1012294324713.

Bowles, S., Gintis, H., Osborne, M., 2001. Incentive-enhancing preferences: Personality, behavior, and earnings. The American Economic Review 91, 155-158.

Braakmann, N., 2009. The Role of Psychological Traits for the Gender Gap in Full-Time Employment and Wages: Evidence from Germany. SOEP Discussion Paper 162. doi:10.2139/ssrn. 1357346. 
Card, D., Cardoso, A.R., Kline, P., 2016. Bargaining, Sorting, and the Gender Wage Gap: Quantifying the Impact of Firms on the Relative Pay of Women. The Quarterly Journal of Economics 131, 633-686. doi:10.1093/qje/qjv038.

Christofides, L.N., Polycarpou, A., Vrachimis, K., 2013. Gender wage gaps, 'sticky floors' and 'glass ceilings' in Europe. Labour Economics 21, 86-102. doi:10.1016/j . labeco.2013.01.003.

Cobb-Clark, D.A., Schurer, S., 2012. The stability of big-five personality traits. Economics Letters 115, 11-15. doi:10.1016/j.econlet.2011.11.015.

Cobb-Clark, D.A., Schurer, S., 2013. Two Economists' Musings on the Stability of Locus of Control. The Economic Journal 123, 358-400. doi:10.1111/ecoj. 12069.

Collischon, M., 2017a. Is there a Glass Ceiling over Germany? BGPE Discussion Paper 175. doi:10.2139/ssrn. 3067365 .

Collischon, M., 2017b. The Returns to Personality Traits across the Wage Distribution. SOEP Discussion Paper 921. doi:10.2139/ssrn. 3043648.

Costa, P.T., McCrae, R.R., 1994. Set like plaster? Evidence for the stability of adult personality, in: Heatherton, T.F., Weinberger, J.L. (Eds.), Can personality change?. American Psychological Association, Washington, pp. 21-40. doi:10.1037/10143-002.

Dehne, M., Schupp, J., 2007. Persönlichkeitsmerkmale im Sozio-oekonomischen Panel (SOEP) Konzept, Umsetzung und empirische Eigenschaften. DIW Research Note 26 .

Elder, T.E., Goddeeris, J.H., Haider, S.J., 2010. Unexplained gaps and Oaxaca-Blinder decompositions. Labour Economics 17, 284-290. doi:10.1016/j. labeco.2009.11.002.

Elkins, R.K., Kassenboehmer, S.C., Schurer, S., 2017. The stability of personality traits in adolescence and young adulthood. Journal of Economic Psychology doi:10.1016/j. joep. 2016.12. 005. 
Finke, C., 2010. Verdienstunterschiede zwischen Männern und Frauen. Statistisches Bundesamt, Wiesbaden.

Firpo, S., Fortin, N.M., Lemieux, T., 2009. Unconditional Quantile Regressions. Econometrica 77, 953-973. doi:10.3982/ECTA6822.

Fortin, N., Lemieux, T., Firpo, S., 2011. Decomposition Methods in Economics, in: Ashenfelter, O., Card, D. (Eds.), Handbook of Labor Economics. North Holland, Amsterdam. volume 4A, pp. 1-102. doi:10.1016/S0169-7218(11)00407-2.

Fortin, N.M., 2008. The Gender Wage Gap among Young Adults in the United States: The Importance of Money versus People. The Journal of Human Resources 43, 884-918.

Goldin, C., 2014. A Pollution Theory of Discrimination: Male and Female Differences in Occupations and Earnings, in: Leah Platt Boustan, Carola Frydman, Robert A. Margo (Eds.), Human Capital in History: The American Record. University of Chicago Press, pp. 313-348. URL: http: //www. nber .org/chapters/c12904, doi:10.7208/chicago/9780226163925.003.0010.

Heckman, J.J., 1979. Sample Selection Bias as a Specification Error. Econometrica 47, 153-161.

Heineck, G., 2011. Does it pay to be nice? Personality and Earnings in the United Kingdom. Industrial and Labor Relations Review 64, 1020-1038. doi:10.1177/001979391106400509.

Heineck, G., Anger, S., 2010. The returns to cognitive abilities and personality traits in Germany. Labour Economics 17, 535-546. doi:10.1016/j. labeco. 2009.06.001.

Heinz, M., Normann, H.T., Rau, H.A., 2016. How competitiveness may cause a gender wage gap: Experimental evidence. European Economic Review 90, 336-349. doi:10.1016/j. euroecorev. 2016.02 .011

Huffman, M.L., King, J., Reichelt, M., 2016. Equality for whom? organizational policies and the gender gap across the german earnings distribution. ILR Review 70, 16-41. doi:10.1177/ 0019793916673974. 
Judge, T.A., Higgins, C.A., Thoresen, C.J., Barrick, M.R., 1999. The Big Five Personality Traits, general mental ability, and Career Success across the Life Span. Personnel Psychology 52, 621-652. doi:10.1111/j.1744-6570.1999. tb00174.x.

Kee, H.J., 2006. Glass Ceiling or Sticky Floor? Exploring the Australian Gender Pay Gap. Economic Record 82,408-427. doi:10.1111/j.1475-4932.2006.00356.x.

Koenker, R., Bassett, G., 1978. Regression Quantiles. Econometrica 46, 33-50. doi:10.2307/ 1913643.

Lazear, E.P., Rosen, S., 1990. Male-Female Wage Differentials in Job Ladders. Journal of Labor Economics 8, S106-S123. doi:10.1086/298246.

Losoncz, I., 2009. Personality traits in HILDA. Australian Social Policy 8, 169-198.

McCrae, R.R., Costa, P.T., 2008. The five-factor theory of personality, in: John, O.P., Robins, R.W., Pervin, L.A. (Eds.), Handbook of personality. Guilford Press, New York.

McGee, A., McGee, P., Pan, J., 2015. Performance pay, competitiveness, and the gender wage gap: Evidence from the United States. Economics Letters 128, 35-38. doi:10.1016/j.econlet. 2015.01 .004$.

Mueller, G., Plug, E., 2006. Estimating the Effect of Personality on Male and Female Earnings. Industrial and Labor Relations Review 60, 3-22. doi:10.1177/001979390606000101.

Neumark, D., 1988. Employers' discriminatory behavior and the estimation of wage discrimination. The Journal of Human Resources 23, 279-295. URL: http: //www. jstor . org/stable/145830, doi:10.2307/145830.

Niederle, M., Vesterlund, L., 2007. Do Women Shy Away From Competition? Do Men Compete Too Much? The Quarterly Journal of Economics 122, 1067-1101. doi:10.1162/qjec.122.3.1067.

Nyhus, E.K., Pons, E., 2005. The effects of personality on earnings. Journal of Economic Psychology 26, 363-384. doi:10.1016/j.joep.2004.07.001. 
Nyhus, E.K., Pons, E., 2012. Personality and the gender wage gap. Applied Economics 44, 105-118. doi:10.1080/00036846.2010.500272.

Oaxaca, R., 1973. Male-female wage differentials in urban labor markets. International Economic Review 14, 693-709. doi:10.2307/2525981.

Oaxaca, R.L., Ransom, M.R., 1994. On discrimination and the decomposition of wage differentials. Journal of Econometrics 61, 5-21. doi:10.1016/0304-4076(94)90074-4.

Ridgeway, C.L., 2001. Gender, status, and leadership. Journal of Social Issues 57, 637-655. doi:10.1111/0022-4537.00233.

Rotter, J.B., 1966. Generalized expectancies for internal versus external control of reinforcement. Psychological Monographs: General and Applied 80, 1-28. doi:10.1037/h0092976.

Schmitt, D.P., Realo, A., Voracek, M., Allik, J., 2008. Why can't a man be more like a woman? sex differences in big five personality traits across 55 cultures. Journal of Personality and Social Psychology 94, 168-182. doi:10.1037/0022-3514.94.1.168.

Semykina, A., Linz, S.J., 2007. Gender differences in personality and earnings: Evidence from Russia. Journal of Economic Psychology 28, 387-410. doi:10.1016/j.joep.2006.05.004.

Socio-Economic Panel (SOEP), 2016. Data from 1984-2015, version 32. doi:10.5684/soep.v32.

Stuhlmacher, A.F., Walters, A.E., 1999. Gender Differences in Negotiation Outcome: A metaanalysis. Personnel Psychology 52,653-677. doi:10.1111/j.1744-6570.1999.tb00175.x.

Thévenon, O., 2013. Drivers of female labor force participation in the oecd. OECD Social, Employment and Migration Working Paper No.145 doi:10.1787/5k46cvrgnms6-en.

University of Essex. Institute for Social and Economic Research NatCen Social Research Kantar Public, 2016. Understanding Society: Waves 1-6, 2009-2015. doi:10.5255/UKDA-SN-6614-9. 
Wagner, G., Frick, J.R., 2007. The German Socio-Economic Panel Study (SOEP) - Scope, Evolution and Enhancements. Schmollers Jahrbuch 127, 139-169.

Wooden, M., Watson, N., 2007. The HILDA Survey and its Contribution to Economic and Social Research (So Far). Economic Record 83, 208-231. doi:10.1111/j.1475-4932.2007.00395.x. 
Table 1: Descriptive statistics of personality traits skills by gender.

\begin{tabular}{|c|c|c|c|c|c|c|c|c|c|}
\hline & \multicolumn{3}{|c|}{ Germany (SOEP, N=152,777) } & \multicolumn{3}{|c|}{ UK (UKHLS, N=68,614) } & \multicolumn{3}{|c|}{ Australia (HILDA, N=49,514) } \\
\hline & Male & Female & Difference & Male & Female & Difference & Male & Female & Difference \\
\hline Extraversion & -0.109 & 0.141 & $-0.249^{* * *}$ & -0.118 & 0.132 & $-0.250^{* * *}$ & -0.128 & 0.138 & $-0.266^{* * *}$ \\
\hline Agreeableness & -0.170 & 0.147 & $-0.318^{* * *}$ & -0.175 & 0.157 & $-0.332^{* * *}$ & -0.238 & 0.270 & $-0.508^{* * *}$ \\
\hline Conscientiousness & -0.033 & 0.117 & $-0.150^{* * *}$ & -0.057 & 0.193 & $-0.250^{* * *}$ & -0.016 & 0.203 & $-0.220^{* * *}$ \\
\hline Neuroticism & -0.268 & 0.112 & $-0.380^{* * *}$ & -0.271 & 0.109 & $-0.380^{* * *}$ & 0.019 & 0.022 & -0.003 \\
\hline Openness & -0.074 & 0.089 & $-0.162^{* * *}$ & 0.135 & -0.011 & $0.146^{* * *}$ & 0.054 & -0.045 & $0.099^{* * *}$ \\
\hline Locus of control & -0.135 & -0.019 & $-0.116^{* * *}$ & & & & -0.109 & -0.099 & -0.010 \\
\hline Positive reciprocity & 0.050 & 0.027 & $0.023^{* * *}$ & & & & & & \\
\hline Negative reciprocity & 0.146 & -0.131 & $0.276^{* * *}$ & & & & & & \\
\hline Risk taking & 0.218 & -0.139 & $0.357^{* * *}$ & & & & & & \\
\hline
\end{tabular}

Notes: Mean values of personality traits by gender and comparisons of these via t-tests. Significance levels: ${ }^{+} p<0.10,{ }^{*} p<0.05,{ }^{* *} p<0.01$, ${ }^{* * *} p<0.001$. Sources: SOEP v32 1991-2015, UKHLS 2009-2015, HILDA 2001-2015. 
Table 2: Results of the FFL-decompositions.

\begin{tabular}{|c|c|c|c|c|c|c|c|c|c|c|c|c|}
\hline & \multicolumn{4}{|c|}{ Germany (SOEP, N=152,777) } & \multicolumn{4}{|c|}{ United Kingdom (UKHLS, N=68,614) } & \multicolumn{4}{|c|}{ Australia $(\mathrm{HILDA}, \mathrm{N}=49,514)$} \\
\hline & Mean & $\begin{array}{c}10^{t h} \\
\text { Percentile }\end{array}$ & $\begin{array}{c}50^{t h} \\
\text { Percentile }\end{array}$ & $\begin{array}{c}90^{t h} \\
\text { Percentile }\end{array}$ & Mean & $\begin{array}{c}10^{t h} \\
\text { Percentile }\end{array}$ & $\begin{array}{c}50^{t h} \\
\text { Percentile }\end{array}$ & $\begin{array}{c}90^{t h} \\
\text { Percentile }\end{array}$ & Mean & $\begin{array}{c}10^{t h} \\
\text { Percentile }\end{array}$ & $\begin{array}{c}50^{t h} \\
\text { Percentile }\end{array}$ & $\begin{array}{c}90^{t h} \\
\text { Percentile }\end{array}$ \\
\hline Raw Gap & $\begin{array}{l}0.273^{* * *} \\
(0.008)\end{array}$ & $\begin{array}{l}0.287^{* * *} \\
(0.014)\end{array}$ & $\begin{array}{l}0.256^{* * *} \\
(0.008)\end{array}$ & $\begin{array}{l}0.300^{* * *} \\
(0.013)\end{array}$ & $\begin{array}{l}0.190^{* * *} \\
(0.008)\end{array}$ & $\begin{array}{l}0.090^{* * *} \\
(0.007)\end{array}$ & $\begin{array}{l}0.224^{* * *} \\
(0.011)\end{array}$ & $\begin{array}{l}0.257^{* * *} \\
(0.016)\end{array}$ & $\begin{array}{l}0.168^{* * *} \\
(0.009)\end{array}$ & $\begin{array}{l}0.091^{* * *} \\
(0.009)\end{array}$ & $\begin{array}{l}0.158^{* * *} \\
(0.009)\end{array}$ & $\begin{array}{c}0.255^{* * *} \\
(0.015)\end{array}$ \\
\hline \multicolumn{13}{|c|}{ (A) without personality traits } \\
\hline $\begin{array}{l}\text { Explained } \\
\text { Unexplained }\end{array}$ & $\begin{array}{c}0.173^{* * *} \\
(0.007) \\
0.101^{* * *} \\
(0.006) \\
\end{array}$ & $\begin{array}{c}0.399^{* * *} \\
(0.011) \\
-0.112^{* * *} \\
(0.013) \\
\end{array}$ & $\begin{array}{c}0.109^{* * *} \\
(0.006) \\
0.147^{* * *} \\
(0.007) \\
\end{array}$ & $\begin{array}{c}0.076^{* * *} \\
(0.008) \\
0.224^{* * *} \\
(0.012) \\
\end{array}$ & $\begin{array}{c}0.030^{* * *} \\
(0.005) \\
0.160^{* * *} \\
(0.007) \\
\end{array}$ & $\begin{array}{c}0.054^{* * *} \\
(0.004) \\
0.036^{* * *} \\
(0.007) \\
\end{array}$ & $\begin{array}{c}0.042^{* * *} \\
(0.006) \\
0.183^{* * *} \\
(0.009) \\
\end{array}$ & $\begin{array}{c}0.003 \\
(0.006) \\
0.255^{* * *} \\
(0.015) \\
\end{array}$ & $\begin{array}{c}0.003 \\
(0.006) \\
0.165^{* * *} \\
(0.008) \\
\end{array}$ & $\begin{array}{c}0.020^{* * *} \\
(0.005) \\
0.071^{* * *} \\
(0.009) \\
\end{array}$ & $\begin{array}{c}0.001 \\
(0.006) \\
0.157^{* * *} \\
(0.008) \\
\end{array}$ & $\begin{array}{c}-0.014^{*} \\
(0.007) \\
0.269^{* * *} \\
(0.014) \\
\end{array}$ \\
\hline \multicolumn{13}{|c|}{ (B) with personality traits } \\
\hline $\begin{array}{l}\text { Explained } \\
\text { Unexplained } \\
\text { Detailed decomposition }\end{array}$ & $\begin{array}{c}0.188^{* * *} \\
(0.007) \\
0.086^{* * *} \\
(0.006)\end{array}$ & $\begin{array}{c}0.399^{* * *} \\
(0.012) \\
-0.112^{* * *} \\
(0.014)\end{array}$ & $\begin{array}{c}0.125^{* * *} \\
(0.006) \\
0.131^{* * *} \\
(0.007)\end{array}$ & $\begin{array}{l}0.105^{* * *} \\
(0.009) \\
0.196^{* * *} \\
(0.012)\end{array}$ & $\begin{array}{c}0.043^{* * *} \\
(0.006) \\
0.148^{* * *} \\
(0.008)\end{array}$ & $\begin{array}{c}0.054^{* * *} \\
(0.005) \\
0.036^{* * *} \\
(0.007)\end{array}$ & $\begin{array}{c}0.052^{* * *} \\
(0.007) \\
0.172^{* * *} \\
(0.010)\end{array}$ & $\begin{array}{c}0.026^{* *} \\
(0.008) \\
0.231^{* * *} \\
(0.016)\end{array}$ & $\begin{array}{c}0.016^{* *} \\
(0.006) \\
0.152^{* * *} \\
(0.008)\end{array}$ & $\begin{array}{c}0.026^{* * *} \\
(0.006) \\
0.065^{* * *} \\
(0.009)\end{array}$ & $\begin{array}{c}0.012^{+} \\
(0.007) \\
0.145^{* * *} \\
(0.008)\end{array}$ & $\begin{array}{c}0.007 \\
(0.009) \\
0.248^{* * *} \\
(0.015)\end{array}$ \\
\hline $\begin{array}{l}\text { Explained } \\
\text { Extraversion } \\
\text { Agreeableness } \\
\text { Conscientiousness } \\
\text { Neuroticism } \\
\text { Openness } \\
\text { Locus of control } \\
\text { Positive reciprocity } \\
\text { Negative reciprocity } \\
\text { Risk taking }\end{array}$ & $\begin{array}{l}0.001 \\
0.008^{* * *} \\
0.000 \\
0.004^{* * *} \\
-0.002^{* *} \\
0.005^{* * *} \\
0.000 \\
-0.001 \\
0.002^{*}\end{array}$ & $\begin{array}{l}0.001 \\
0.003^{+} \\
-0.001 \\
0.003 \\
0.000 \\
0.005^{* * *} \\
0.000 \\
-0.002 \\
-0.007^{* * *}\end{array}$ & $\begin{array}{l}0.001 \\
0.008^{* * *} \\
0.001^{* *} \\
0.004^{* *} \\
-0.002^{* * *} \\
0.004^{* * *} \\
0.000 \\
-0.002^{+} \\
0.003^{* *}\end{array}$ & $\begin{array}{l}0.001 \\
0.011^{* * *} \\
-0.001 \\
0.007^{* *} \\
-0.001 \\
0.007^{* * *} \\
0.00 \\
0.001 \\
0.009^{* * *}\end{array}$ & $\begin{array}{r}-0.003^{* *} \\
0.010^{* * *} \\
-0.005^{* * *} \\
0.011^{* * *} \\
0.001\end{array}$ & $\begin{array}{l}-0.001 \\
0.003^{*} \\
-0.004^{* * *} \\
0.004^{* *} \\
-0.001\end{array}$ & $\begin{array}{r}-0.004^{* * *} \\
0.010^{* * *} \\
-0.005^{* * *} \\
0.010^{* * *} \\
0.002^{*}\end{array}$ & $\begin{array}{c}-0.001 \\
0.015^{* * *} \\
-0.006^{* *} \\
0.014^{* * *} \\
0.003^{*}\end{array}$ & $\begin{array}{l}0.000 \\
0.019^{* * *} \\
-0.005^{* * *} \\
0.000 \\
0.000 \\
0.000\end{array}$ & $\begin{array}{c}0.001 \\
0.010^{* * *} \\
-0.003^{*} \\
0.000 \\
-0.001 \\
0.000\end{array}$ & $\begin{array}{l}0.000 \\
0.016^{* * *} \\
-0.004^{* * *} \\
0.000 \\
0.000 \\
0.000\end{array}$ & $\begin{array}{l}0.000 \\
0.030^{* * *} \\
-0.007^{* * *} \\
0.000 \\
0.001 \\
0.001\end{array}$ \\
\hline $\begin{array}{l}\text { Unexplained } \\
\text { Extraversion } \\
\text { Agreeableness } \\
\text { Conscientiousness } \\
\text { Neuroticism } \\
\text { Openness } \\
\text { Locus of control } \\
\text { Positive reciprocity } \\
\text { Negative reciprocity } \\
\text { Risk taking }\end{array}$ & $\begin{array}{l}0.000 \\
0.000 \\
0.000 \\
0.001^{*} \\
0.000 \\
0.001^{*} \\
0.000 \\
0.000 \\
0.001^{*}\end{array}$ & $\begin{array}{c}0.001^{*} \\
-0.001^{*} \\
0.001^{+} \\
0.001 \\
-0.001^{*} \\
-0.002^{*} \\
0.001 \\
0.000 \\
0.001^{+}\end{array}$ & $\begin{array}{l}0.000 \\
0.000 \\
0.000 \\
0.001 \\
0.000 \\
0.001 \\
0.000 \\
0.000 \\
0.000\end{array}$ & $\begin{array}{l}-0.001^{* *} \\
0.001^{* *} \\
0.000 \\
0.002^{+} \\
0.000 \\
0.003^{* * *} \\
0.001 \\
0.000 \\
0.001\end{array}$ & $\begin{array}{l}0.000 \\
0.000^{+} \\
0.001^{+} \\
0.002^{*} \\
0.001\end{array}$ & $\begin{array}{c}0.000 \\
-0.001^{* *} \\
0.000 \\
-0.002^{* *} \\
0.001\end{array}$ & $\begin{array}{c}0.000 \\
-0.001^{* * *} \\
0.000 \\
0.001 \\
0.001\end{array}$ & $\begin{array}{l}0.000 \\
0.001 \\
0.002^{*} \\
0.007^{* * *} \\
0.001\end{array}$ & $\begin{array}{r}0.000 \\
-0.001 \\
0.000 \\
0.000 \\
0.000 \\
0.002^{* *}\end{array}$ & $\begin{array}{r}0.000 \\
0.000 \\
-0.001 \\
0.000 \\
0.000 \\
0.000\end{array}$ & $\begin{array}{c}0.000 \\
-0.001^{*} \\
0.000 \\
0.000 \\
0.000 \\
0.001\end{array}$ & $\begin{array}{c}-0.001^{*} \\
0.000 \\
0.001 \\
0.000 \\
0.000 \\
0.004^{* *}\end{array}$ \\
\hline
\end{tabular}

Notes: Cluster-robust standard errors in parentheses. The dependent variable is the natural logarithm of the hourly wage. Every estimation accounts for the full set of control variables. Significance levels: ${ }^{+} p<0.10,{ }^{*} p<0.05,{ }^{* *} p<0.01,{ }^{* * *} p<0.001$. Sources: SOEP v32 1991-2015, UKHLS 2009-2015, HILDA 2001-2015. 
Table 3: Results of the FFL-decompositions with controls for industry \& occupation.

\begin{tabular}{|c|c|c|c|c|c|c|c|c|c|c|c|c|}
\hline & \multicolumn{4}{|c|}{ Germany (SOEP, N=152,777) } & \multicolumn{4}{|c|}{ United Kingdom (UKHLS, N=68,614) } & \multicolumn{4}{|c|}{ Australia (HILDA, N=49,514) } \\
\hline & Mean & $\begin{array}{c}10^{t h} \\
\text { Percentile }\end{array}$ & $\begin{array}{c}50^{t h} \\
\text { Percentile }\end{array}$ & $\begin{array}{c}90^{t h} \\
\text { Percentile }\end{array}$ & Mean & $\begin{array}{c}10^{t h} \\
\text { Percentile }\end{array}$ & $\begin{array}{c}50^{t h} \\
\text { Percentile }\end{array}$ & $\begin{array}{c}90^{\text {th }} \\
\text { Percentile }\end{array}$ & Mean & $\begin{array}{c}10^{t h} \\
\text { Percentile }\end{array}$ & $\begin{array}{c}50^{t h} \\
\text { Percentile }\end{array}$ & $\begin{array}{c}90^{t h} \\
\text { Percentile }\end{array}$ \\
\hline Raw Gap & $\begin{array}{l}0.273^{* * *} \\
(0.008)\end{array}$ & $\begin{array}{l}0.287^{* * *} \\
(0.014)\end{array}$ & $\begin{array}{l}0.256^{* * *} \\
(0.008)\end{array}$ & $\begin{array}{l}0.300^{* * *} \\
(0.013)\end{array}$ & $\begin{array}{l}0.190^{* * *} \\
(0.008)\end{array}$ & $\begin{array}{l}0.090^{* * *} \\
(0.007)\end{array}$ & $\begin{array}{l}0.224^{* * *} \\
(0.010)\end{array}$ & $\begin{array}{l}0.257^{* * *} \\
(0.015)\end{array}$ & $\begin{array}{l}0.168^{* * *} \\
(0.008)\end{array}$ & $\begin{array}{l}0.091^{* * *} \\
(0.009)\end{array}$ & $\begin{array}{l}0.158^{* * *} \\
(0.009)\end{array}$ & $\begin{array}{c}0.255^{* * *} \\
(0.014)\end{array}$ \\
\hline \multicolumn{13}{|c|}{ (A) without personality traits } \\
\hline $\begin{array}{l}\text { Explained } \\
\text { Unexplained }\end{array}$ & $\begin{array}{c}0.166^{* * *} \\
(0.007) \\
0.107^{* * *} \\
(0.007)\end{array}$ & $\begin{array}{c}0.362^{* * *} \\
(0.013) \\
-0.076^{* * *} \\
(0.014)\end{array}$ & $\begin{array}{c}0.108^{* * *} \\
(0.007) \\
0.148^{* * *} \\
(0.007)\end{array}$ & $\begin{array}{c}0.093^{* * *} \\
(0.010) \\
0.207^{* * *} \\
(0.013)\end{array}$ & $\begin{array}{c}0.043^{* * *} \\
(0.007) \\
0.147^{* * *} \\
(0.007)\end{array}$ & $\begin{array}{c}0.036^{* * *} \\
(0.005) \\
0.054^{* * *} \\
(0.007)\end{array}$ & $\begin{array}{c}0.058^{* * *} \\
(0.008) \\
0.167^{* * *} \\
(0.009)\end{array}$ & $\begin{array}{l}0.049^{* * *} \\
(0.010) \\
0.208^{* * *} \\
(0.016)\end{array}$ & $\begin{array}{l}0.063^{* * *} \\
(0.007) \\
0.105^{* * *} \\
(0.007)\end{array}$ & $\begin{array}{c}0.041^{* * *} \\
(0.007) \\
0.050^{* * *} \\
(0.010)\end{array}$ & $\begin{array}{c}0.053^{* * *} \\
(0.008) \\
0.104^{* * *} \\
(0.008)\end{array}$ & $\begin{array}{c}0.093^{* * *} \\
(0.010) \\
0.162^{* * *} \\
(0.014)\end{array}$ \\
\hline \multicolumn{13}{|c|}{ (B) with personality traits } \\
\hline $\begin{array}{l}\text { Explained } \\
\text { Unexplained } \\
\text { Detailed decomposition }\end{array}$ & $\begin{array}{c}0.178^{* * *} \\
(0.008) \\
0.095^{* * *} \\
(0.007)\end{array}$ & $\begin{array}{c}0.364^{* * *} \\
(0.014) \\
-0.077^{* * *} \\
(0.015)\end{array}$ & $\begin{array}{c}0.120^{* * *} \\
(0.007) \\
0.135^{* * *} \\
(0.007)\end{array}$ & $\begin{array}{c}0.114^{* * *} \\
(0.011) \\
0.186^{* * *} \\
(0.014)\end{array}$ & $\begin{array}{l}0.051^{* * * *} \\
(0.007) \\
0.139^{* * *} \\
(0.008)\end{array}$ & $\begin{array}{c}0.036^{* * *} \\
(0.006) \\
0.055^{* * *} \\
(0.008)\end{array}$ & $\begin{array}{c}0.063^{* * *} \\
(0.009) \\
0.161^{* * *} \\
(0.010)\end{array}$ & $\begin{array}{l}0.067^{* * *} \\
(0.011) \\
0.191^{* * *} \\
(0.017)\end{array}$ & $\begin{array}{c}0.069^{* * *} \\
(0.007) \\
0.099^{* * *} \\
(0.007)\end{array}$ & $\begin{array}{c}0.043^{* * *} \\
(0.008) \\
0.048^{* * *} \\
(0.010)\end{array}$ & $\begin{array}{l}0.058^{* * *} \\
(0.008) \\
0.100^{* * *} \\
(0.008)\end{array}$ & $\begin{array}{c}0.104^{* * *} \\
(0.011) \\
0.151^{* * *} \\
(0.014)\end{array}$ \\
\hline $\begin{array}{l}\text { Explained } \\
\quad \text { Extraversion } \\
\text { Agreeableness } \\
\text { Conscientiousness } \\
\text { Neuroticism } \\
\text { Openness } \\
\text { Locus of control } \\
\text { Positive reciprocity } \\
\text { Negative reciprocity } \\
\text { Risk taking }\end{array}$ & $\begin{array}{l}0.000 \\
0.006^{* * *} \\
-0.001 \\
0.003^{* *} \\
0.000 \\
0.004^{* * *} \\
0.000 \\
0.000 \\
0.003^{* * *}\end{array}$ & $\begin{array}{c}0.001 \\
0.003 \\
-0.002^{+} \\
0.001 \\
0.001 \\
0.005^{* * *} \\
0.000 \\
0.000 \\
-0.004^{*}\end{array}$ & $\begin{array}{l}0.000 \\
0.006^{* * *} \\
0.000 \\
0.002^{*} \\
0.000 \\
0.002^{* * *} \\
0.000 \\
0.000 \\
0.004^{* * *}\end{array}$ & $\begin{array}{l}0.000 \\
0.009^{* * *} \\
-0.001^{+} \\
0.005^{* *} \\
0.000 \\
0.005^{* * *} \\
0.000 \\
0.001 \\
0.007^{* * *}\end{array}$ & $\begin{array}{r}-0.002^{*} \\
0.008^{* * *} \\
-0.004^{* * *} \\
0.010^{* * *} \\
0.000\end{array}$ & $\begin{array}{c}-0.001 \\
0.003^{*} \\
-0.004^{* * *} \\
0.005^{* * *} \\
-0.001^{*}\end{array}$ & $\begin{array}{c}-0.003^{* *} \\
0.007^{* * *} \\
-0.003^{* *} \\
0.008^{* * *} \\
0.000\end{array}$ & $\begin{array}{l}0.000 \\
0.012^{* * *} \\
-0.005^{* *} \\
0.012^{* * *} \\
0.002^{*}\end{array}$ & $\begin{array}{l}0.001 \\
0.012^{* * *} \\
-0.003^{* * *} \\
0.000 \\
0.000 \\
0.000\end{array}$ & $\begin{array}{c}0.001 \\
0.006^{*} \\
-0.002^{+} \\
0.000 \\
-0.001^{*} \\
0.000\end{array}$ & $\begin{array}{l}0.001 \\
0.010^{* * *} \\
-0.003^{* * *} \\
0.000 \\
0.000 \\
0.000\end{array}$ & $\begin{array}{l}0.000 \\
0.020^{* * *} \\
-0.004^{* *} \\
0.000 \\
0.000 \\
0.000\end{array}$ \\
\hline $\begin{array}{l}\text { Unexplained } \\
\text { Extraversion } \\
\text { Agreeableness } \\
\text { Conscientiousness } \\
\text { Neuroticism } \\
\text { Openness } \\
\text { Locus of control } \\
\text { Positive reciprocity } \\
\text { Negative reciprocity } \\
\text { Risk taking }\end{array}$ & $\begin{array}{l}0.000 \\
0.000 \\
0.000 \\
0.001^{* *} \\
0.000 \\
0.001^{*} \\
0.000^{*} \\
0.000 \\
0.000\end{array}$ & $\begin{array}{c}0.001 \\
-0.001 \\
0.001 \\
0.002^{*} \\
0.000 \\
-0.001 \\
0.001^{*} \\
0.000 \\
0.001^{+}\end{array}$ & $\begin{array}{l}0.000 \\
0.000 \\
0.000 \\
0.001 \\
0.000 \\
0.001 \\
0.000 \\
0.000 \\
0.000\end{array}$ & $\begin{array}{c}-0.001^{*} \\
0.001^{* *} \\
0.000 \\
0.001 \\
0.000 \\
0.002^{* *} \\
0.001 \\
-0.001^{+} \\
0.000\end{array}$ & $\begin{array}{c}0.000 \\
-0.001^{* *} \\
0.001^{*} \\
0.002^{*} \\
-0.001\end{array}$ & $\begin{array}{c}0.000 \\
0.000^{+} \\
0.000 \\
-0.002^{* *} \\
0.000\end{array}$ & $\begin{array}{c}0.000 \\
-0.002^{* * *} \\
0.000 \\
0.001 \\
-0.001\end{array}$ & $\begin{array}{l}0.000 \\
0.000 \\
0.002^{*} \\
0.006^{* *} \\
0.000\end{array}$ & $\begin{array}{l}0.000 \\
0.000 \\
0.000 \\
0.000 \\
0.000 \\
0.002^{*}\end{array}$ & $\begin{array}{r}0.000 \\
0.000 \\
-0.001 \\
0.000 \\
0.000 \\
0.000\end{array}$ & $\begin{array}{c}0.000 \\
-0.001^{+} \\
0.000 \\
0.000 \\
0.000 \\
0.000\end{array}$ & $\begin{array}{l}0.000 \\
0.000 \\
0.000 \\
0.000 \\
0.000 \\
0.003^{*}\end{array}$ \\
\hline
\end{tabular}

Notes: Cluster-robust standard errors in parentheses. The dependent variable is the natural logarithm of the hourly wage. Every estimation accounts for the full set of control variables. Significance levels: ${ }^{+} p<0.10,{ }^{*} p<0.05,{ }^{* *} p<0.01,{ }^{* * *} p<0.001$. Sources: SOEP v32 1991-2015, UKHLS 2009-2015, HILDA 2001-2015. 
Table 4: Results of the FFL-decompositions with imputed wages and minmal controls.

\begin{tabular}{|c|c|c|c|c|c|c|c|c|c|c|c|c|}
\hline & \multicolumn{4}{|c|}{ Germany (SOEP, N=204,428) } & \multicolumn{4}{|c|}{ United Kingdom (UKHLS, N=77,930) } & \multicolumn{4}{|c|}{ Australia (HILDA, N=104,704) } \\
\hline & Mean & $\begin{array}{c}10^{t h} \\
\text { Percentile }\end{array}$ & $\begin{array}{c}50^{t h} \\
\text { Percentile }\end{array}$ & $\begin{array}{c}90^{t h} \\
\text { Percentile }\end{array}$ & Mean & $\begin{array}{c}10^{t h} \\
\text { Percentile }\end{array}$ & $\begin{array}{c}50^{t h} \\
\text { Percentile }\end{array}$ & $\begin{array}{c}90^{t h} \\
\text { Percentile }\end{array}$ & Mean & $\begin{array}{c}10^{t h} \\
\text { Percentile }\end{array}$ & $\begin{array}{c}50^{t h} \\
\text { Percentile }\end{array}$ & $\begin{array}{c}90^{t h} \\
\text { Percentile }\end{array}$ \\
\hline Raw Gap & $\begin{array}{l}0.275^{* * *} \\
(0.008)\end{array}$ & $\begin{array}{c}0.253^{* * *} \\
(0.014)\end{array}$ & $\begin{array}{l}0.266^{* * *} \\
(0.008)\end{array}$ & $\begin{array}{l}0.311^{* * *} \\
(0.013)\end{array}$ & $\begin{array}{l}0.183^{* * *} \\
(0.009)\end{array}$ & $\begin{array}{l}0.081^{* * *} \\
(0.007)\end{array}$ & $\begin{array}{c}0.217^{* * *} \\
(0.010)\end{array}$ & $\begin{array}{l}0.250^{* * *} \\
(0.015)\end{array}$ & $\begin{array}{l}0.119^{* * *} \\
(0.008)\end{array}$ & $\begin{array}{l}0.047^{* * *} \\
(0.011)\end{array}$ & $\begin{array}{l}0.120^{* * *} \\
(0.008)\end{array}$ & $\begin{array}{l}0.202^{* * *} \\
(0.013)\end{array}$ \\
\hline \multicolumn{13}{|c|}{ (A) without personality traits } \\
\hline $\begin{array}{l}\text { Explained } \\
\text { Unexplained }\end{array}$ & $\begin{array}{c}0.015^{* *} \\
(0.005) \\
0.260^{* * *} \\
(0.006)\end{array}$ & $\begin{array}{c}0.014^{*} \\
(0.006) \\
0.239^{* * *} \\
(0.013)\end{array}$ & $\begin{array}{c}0.011^{* *} \\
(0.004) \\
0.254^{* * *} \\
(0.007)\end{array}$ & $\begin{array}{c}0.020^{* *} \\
(0.006) \\
0.291^{* * *} \\
(0.011)\end{array}$ & $\begin{array}{c}-0.006 \\
(0.004) \\
0.189^{* * *} \\
(0.007)\end{array}$ & $\begin{array}{c}-0.006^{*} \\
(0.003) \\
0.088^{* * *} \\
(0.007)\end{array}$ & $\begin{array}{c}-0.012^{*} \\
(0.005) \\
0.230^{* * *} \\
(0.009)\end{array}$ & $\begin{array}{c}0.010^{*} \\
(0.005) \\
0.239^{* * *} \\
(0.014)\end{array}$ & $\begin{array}{c}-0.018^{* * *} \\
(0.004) \\
0.138^{* * *} \\
(0.007)\end{array}$ & $\begin{array}{c}-0.008^{*} \\
(0.003) \\
0.055^{* * *} \\
(0.011)\end{array}$ & $\begin{array}{c}-0.018^{* * *} \\
(0.004) \\
0.138^{* * *} \\
(0.007)\end{array}$ & $\begin{array}{c}-0.028^{* * *} \\
(0.005) \\
0.229^{* * *} \\
(0.013)\end{array}$ \\
\hline \multicolumn{13}{|c|}{ (B) with personality traits } \\
\hline $\begin{array}{l}\text { Explained } \\
\text { Unexplained } \\
\text { Detailed decomposition }\end{array}$ & $\begin{array}{c}0.041^{* * *} \\
(0.006) \\
0.234^{* * *} \\
(0.007)\end{array}$ & $\begin{array}{c}0.031^{\text {*** }} \\
(0.008) \\
0.221^{* * *} \\
(0.014)\end{array}$ & $\begin{array}{c}0.033^{* * *} \\
(0.005) \\
0.233^{* * *} \\
(0.007)\end{array}$ & $\begin{array}{c}0.059^{* * *} \\
(0.008) \\
0.252^{* * *} \\
(0.011)\end{array}$ & $\begin{array}{c}0.010^{+} \\
(0.005) \\
0.173^{* * *} \\
(0.008)\end{array}$ & $\begin{array}{c}-0.005 \\
(0.004) \\
0.087^{* * *} \\
(0.007)\end{array}$ & $\begin{array}{c}0.003 \\
(0.006) \\
0.215^{* * *} \\
(0.010)\end{array}$ & $\begin{array}{c}0.038^{* * *} \\
(0.007) \\
0.211^{* * *} \\
(0.015)\end{array}$ & $\begin{array}{c}-0.011^{*} \\
(0.005) \\
0.130^{* * *} \\
(0.007)\end{array}$ & $\begin{array}{c}-0.011^{*} \\
(0.005) \\
0.059^{* * *} \\
(0.011)\end{array}$ & $\begin{array}{c}-0.011^{*} \\
(0.005) \\
0.131^{* * *} \\
(0.007)\end{array}$ & $\begin{array}{c}-0.010 \\
(0.007) \\
0.212^{* * *} \\
(0.013)\end{array}$ \\
\hline $\begin{array}{l}\text { Explained } \\
\text { Extraversion } \\
\text { Agreeableness } \\
\text { Conscientiousness } \\
\text { Neuroticism } \\
\text { Openness } \\
\text { Locus of control } \\
\text { Positive reciprocity } \\
\text { Negative reciprocity } \\
\text { Risk taking }\end{array}$ & $\begin{array}{l}0.001 \\
0.011^{* * *} \\
-0.001^{* *} \\
0.008^{* * *} \\
0.000 \\
0.006^{* * *} \\
0.000 \\
0.000 \\
0.001\end{array}$ & $\begin{array}{l}0.002 \\
0.011^{* * *} \\
-0.006^{* * *} \\
0.009^{* * *} \\
0.003^{* *} \\
0.006^{* * *} \\
0.001 \\
0.001 \\
-0.010^{* * *}\end{array}$ & $\begin{array}{l}0.001 \\
0.010^{* * *} \\
0.001^{+} \\
0.007^{* * *} \\
-0.001 \\
0.005^{* * *} \\
0.000 \\
-0.002^{*} \\
0.000\end{array}$ & $\begin{array}{l}0.001 \\
0.013^{* * *} \\
-0.001 \\
0.006^{* *} \\
0.000 \\
0.007^{* * *} \\
0.000 \\
0.001 \\
0.010^{* * *}\end{array}$ & $\begin{array}{r}-0.003^{* *} \\
0.011^{* * *} \\
-0.005^{* * *} \\
0.013^{* * *} \\
0.000\end{array}$ & $\begin{array}{c}-0.002^{*} \\
0.004^{* *} \\
-0.005^{* * *} \\
0.006^{* * *} \\
-0.002^{*}\end{array}$ & $\begin{array}{r}-0.005^{* * *} \\
0.012^{* * *} \\
-0.005^{* * *} \\
0.012^{* * *} \\
0.001^{+}\end{array}$ & $\begin{array}{c}-0.002 \\
0.015^{* * *} \\
-0.004^{*} \\
0.016^{* * *} \\
0.003^{*}\end{array}$ & $\begin{array}{l}0.000 \\
0.014^{* * *} \\
-0.007^{* * *} \\
0.000 \\
0.000 \\
0.001\end{array}$ & $\begin{array}{c}0.003^{*} \\
0.002 \\
-0.007^{* * *} \\
0.000 \\
-0.001^{* *} \\
0.000\end{array}$ & $\begin{array}{l}0.000 \\
0.013^{* * *} \\
-0.006^{* * *} \\
0.000 \\
0.000 \\
0.001\end{array}$ & $\begin{array}{c}-0.002 \\
0.026^{* * *} \\
-0.008^{* * *} \\
0.000 \\
0.001 \\
0.001\end{array}$ \\
\hline $\begin{array}{l}\text { Unexplained } \\
\text { Extraversion } \\
\text { Agreeableness } \\
\text { Conscientiousness } \\
\text { Neuroticism } \\
\text { Openness } \\
\text { Locus of control } \\
\text { Positive reciprocity } \\
\text { Negative reciprocity } \\
\text { Risk taking }\end{array}$ & $\begin{array}{l}0.000 \\
-0.001^{* *} \\
0.000 \\
0.001^{* *} \\
0.000 \\
0.000 \\
0.000 \\
0.000 \\
0.000\end{array}$ & $\begin{array}{c}0.001^{+} \\
-0.002^{* * *} \\
0.002^{*} \\
0.001 \\
0.000 \\
-0.002^{+} \\
0.000 \\
0.000^{+} \\
0.001^{+}\end{array}$ & $\begin{array}{l}0.000 \\
-0.001^{* *} \\
0.000 \\
0.001^{+} \\
0.000 \\
0.000 \\
0.000 \\
0.000 \\
0.000\end{array}$ & $\begin{array}{l}-0.001^{* *} \\
0.001^{*} \\
0.000 \\
0.002^{* *} \\
0.000 \\
0.002^{* *} \\
0.000 \\
0.000 \\
0.000\end{array}$ & $\begin{array}{c}0.000 \\
-0.001^{* *} \\
0.001^{+} \\
0.001 \\
0.001\end{array}$ & $\begin{array}{l}0.000 \\
-0.001^{* * *} \\
0.000 \\
-0.003^{* * *} \\
0.000\end{array}$ & $\begin{array}{c}0.000 \\
-0.001^{* * *} \\
0.001 \\
0.000 \\
0.001\end{array}$ & $\begin{array}{l}0.000 \\
0.000 \\
0.001 \\
0.006^{* *} \\
0.001\end{array}$ & $\begin{array}{c}0.000 \\
-0.001^{+} \\
0.000 \\
0.000 \\
0.000 \\
0.002^{*}\end{array}$ & $\begin{array}{r}0.000 \\
0.000 \\
-0.001 \\
0.000 \\
0.000 \\
0.002\end{array}$ & $\begin{array}{c}0.000 \\
-0.001^{*} \\
0.000 \\
0.000 \\
0.000 \\
0.000\end{array}$ & $\begin{array}{l}-0.001^{* *} \\
0.000 \\
0.001^{+} \\
0.000 \\
0.000 \\
0.003^{* *}\end{array}$ \\
\hline
\end{tabular}

Notes: Cluster-robust standard errors in parentheses. The dependent variable is the natural logarithm of the hourly wage. Every estimation accounts for the full set of control variables. Significance levels: ${ }^{+} p<0.10,{ }^{*} p<0.05,{ }^{* *} p<0.01,{ }^{* * *} p<0.001$. Sources: SOEP v32 1991-2015, UKHLS 2009-2015, HILDA 2001-2015. 
Table 5: Unexplained gender wage gaps of the FFL-decompositions, robustness tests.

\begin{tabular}{|c|c|c|c|c|c|c|c|c|c|c|c|c|}
\hline & \multicolumn{4}{|c|}{ Germany (SOEP) } & \multicolumn{4}{|c|}{ United Kingdom (UKHLS) } & \multicolumn{4}{|c|}{ Australia (HILDA) } \\
\hline & Mean & $\begin{array}{c}10^{t h} \\
\text { Percentile }\end{array}$ & $\begin{array}{c}50^{\text {th }} \\
\text { Percentile }\end{array}$ & $\begin{array}{c}90^{\text {th }} \\
\text { Percentile }\end{array}$ & Mean & $\begin{array}{c}10^{\text {th }} \\
\text { Percentile }\end{array}$ & $\begin{array}{c}50^{\text {th }} \\
\text { Percentile }\end{array}$ & $\begin{array}{c}90^{\text {th }} \\
\text { Percentile }\end{array}$ & Mean & $\begin{array}{c}10^{t h} \\
\text { Percentile }\end{array}$ & $\begin{array}{c}50^{t h} \\
\text { Percentile }\end{array}$ & $\begin{array}{c}90^{\text {th }} \\
\text { Percentile }\end{array}$ \\
\hline \multicolumn{13}{|c|}{ (A) Adding survey-specific controls } \\
\hline $\begin{array}{l}\text { W/o personality traits } \\
\text { W/ personality traits }\end{array}$ & $\begin{array}{l}0.109^{* * *} \\
(0.006) \\
0.097^{* * *} \\
(0.007)\end{array}$ & $\begin{array}{c}-0.011 \\
(0.014) \\
-0.012 \\
(0.015)\end{array}$ & $\begin{array}{l}0.130^{* * *} \\
(0.007) \\
0.118^{* * *} \\
(0.007)\end{array}$ & $\begin{array}{l}0.184^{* * *} \\
(0.014) \\
0.163^{* * *} \\
(0.014)\end{array}$ & $\begin{array}{l}0.148^{* * *} \\
(0.007) \\
0.139^{* * *} \\
(0.007)\end{array}$ & $\begin{array}{l}0.055^{* * *} \\
(0.007) \\
0.055^{* * *} \\
(0.007)\end{array}$ & $\begin{array}{l}0.167^{* * *} \\
(0.009) \\
0.161^{* * *} \\
(0.009)\end{array}$ & $\begin{array}{l}0.208^{* * *} \\
(0.016) \\
0.191^{* * *} \\
(0.017)\end{array}$ & $\begin{array}{l}0.103^{* * *} \\
(0.007) \\
0.097^{* * *} \\
(0.007)\end{array}$ & $\begin{array}{l}0.050^{* * *} \\
(0.010) \\
0.047^{* * *} \\
(0.010)\end{array}$ & $\begin{array}{l}0.101^{* * *} \\
(0.008) \\
0.095^{* * *} \\
(0.008)\end{array}$ & $\begin{array}{c}0.160^{* * *} \\
(0.014) \\
0.149^{* * *} \\
(0.014)\end{array}$ \\
\hline \multicolumn{13}{|c|}{ (B) Age 30-55 } \\
\hline $\begin{array}{l}\text { W/o personality traits } \\
\text { W/ personality traits }\end{array}$ & $\begin{array}{l}0.156^{* * *} \\
(0.008) \\
0.144^{* * *} \\
(0.008)\end{array}$ & $\begin{array}{l}0.132^{* * *} \\
(0.014) \\
0.124^{* * *} \\
(0.015)\end{array}$ & $\begin{array}{l}0.153^{* * *} \\
(0.008) \\
0.142^{* * *} \\
(0.008)\end{array}$ & $\begin{array}{l}0.189^{* * *} \\
(0.015) \\
0.174^{* * *} \\
(0.015)\end{array}$ & $\begin{array}{l}0.152^{* * *} \\
(0.009) \\
0.146^{* * *} \\
(0.009)\end{array}$ & $\begin{array}{l}0.084^{* * *} \\
(0.010) \\
0.082^{* * *} \\
(0.011)\end{array}$ & $\begin{array}{l}0.172^{* * *} \\
(0.011) \\
0.169^{* * *} \\
(0.012)\end{array}$ & $\begin{array}{l}0.207^{* * *} \\
(0.020) \\
0.194^{* * *} \\
(0.020)\end{array}$ & $\begin{array}{l}0.123^{* * *} \\
(0.009) \\
0.117^{* * *} \\
(0.010)\end{array}$ & $\begin{array}{l}0.081^{* * *} \\
(0.013) \\
0.074^{* * *} \\
(0.013)\end{array}$ & $\begin{array}{l}0.124^{* * *} \\
(0.010) \\
0.119^{* * *} \\
(0.010)\end{array}$ & $\begin{array}{c}0.173^{* * *} \\
(0.017) \\
0.166^{* * *} \\
(0.018)\end{array}$ \\
\hline \multicolumn{13}{|c|}{ (C) Full time employees } \\
\hline $\begin{array}{l}\text { W/o personality traits } \\
\text { W/ personality traits }\end{array}$ & $\begin{array}{l}0.171^{* * *} \\
(0.007) \\
0.153^{* * *} \\
(0.007)\end{array}$ & $\begin{array}{l}0.185^{* * *} \\
(0.013) \\
0.173^{* * *} \\
(0.013)\end{array}$ & $\begin{array}{l}0.151^{* * *} \\
(0.007) \\
0.136^{* * *} \\
(0.008)\end{array}$ & $\begin{array}{l}0.161^{* * *} \\
(0.013) \\
0.139^{* * *} \\
(0.014)\end{array}$ & $\begin{array}{l}0.142^{* * *} \\
(0.008) \\
0.135^{* * *} \\
(0.008)\end{array}$ & $\begin{array}{l}0.099^{* * *} \\
(0.010) \\
0.103^{* * *} \\
(0.010)\end{array}$ & $\begin{array}{c}0.157^{* * *} \\
(0.009) \\
0.151^{* * *} \\
(0.010)\end{array}$ & $\begin{array}{l}0.167^{* * *} \\
(0.017) \\
0.152^{* * *} \\
(0.017)\end{array}$ & $\begin{array}{c}0.108^{* * *} \\
(0.008) \\
0.102^{* * *} \\
(0.008)\end{array}$ & $\begin{array}{l}0.056^{* * *} \\
(0.011) \\
0.054^{* * *} \\
(0.012)\end{array}$ & $\begin{array}{l}0.107^{* * *} \\
(0.009) \\
0.101^{* * *} \\
(0.009)\end{array}$ & $\begin{array}{c}0.167^{* * *} \\
(0.015) \\
0.154^{* * *} \\
(0.016)\end{array}$ \\
\hline \multicolumn{13}{|c|}{ (D) Heckman (1979) correction } \\
\hline W/o personality traits & $\begin{array}{c}0.053^{* * *} \\
(0.013) \\
0.043^{* * *} \\
(0.009)\end{array}$ & $\begin{array}{c}-0.307^{* * *} \\
(0.023) \\
-0.307^{* * *} \\
(0.016)\end{array}$ & $\begin{array}{c}0.172^{* * *} \\
(0.018) \\
0.161^{* * *} \\
(0.012)\end{array}$ & $\begin{array}{c}0.216^{* * *} \\
(0.021) \\
0.198^{* * *} \\
(0.026)\end{array}$ & $\begin{array}{c}0.155^{\text {*** }} \\
(0.003) \\
0.146^{* * *} \\
(0.008)\end{array}$ & $\begin{array}{c}0.046^{* * *} \\
(0.008) \\
0.047^{* * *} \\
(0.006)\end{array}$ & $\begin{array}{c}0.190^{* * *} \\
(0.014) \\
0.184^{* * *} \\
(0.008)\end{array}$ & $\begin{array}{c}0.205^{\text {*** }} \\
(0.015) \\
0.186^{* * *} \\
(0.028)\end{array}$ & $\begin{array}{c}0.109^{\text {*** }} \\
(0.010) \\
0.103^{* * *} \\
(0.015)\end{array}$ & $\begin{array}{c}0.107^{* * *} \\
(0.012) \\
0.106^{* * *} \\
(0.031)\end{array}$ & $\begin{array}{c}0.131^{* * *} \\
(0.005) \\
0.126^{* * *} \\
(0.012)\end{array}$ & $\begin{array}{c}0.138^{* * *} \\
(0.026) \\
0.128^{* * *} \\
(0.013)\end{array}$ \\
\hline
\end{tabular}

Notes: Cluster-robust standard errors in parentheses; standard errors in the sample-selection estimations are obtained from cluster bootstrapping. The dependent variable is the natural logarithm of the hourly wage. Every estimation accounts for the full set of control variables. Significance levels: ${ }^{+} p<0.10,{ }^{*} p<0.05,{ }^{* *} p<0.01$, ${ }^{* * *} p<0.001$. Sources: SOEP v32 1991-2015, UKHLS 2009-2015, HILDA 2001-2015. 


\section{Germany}

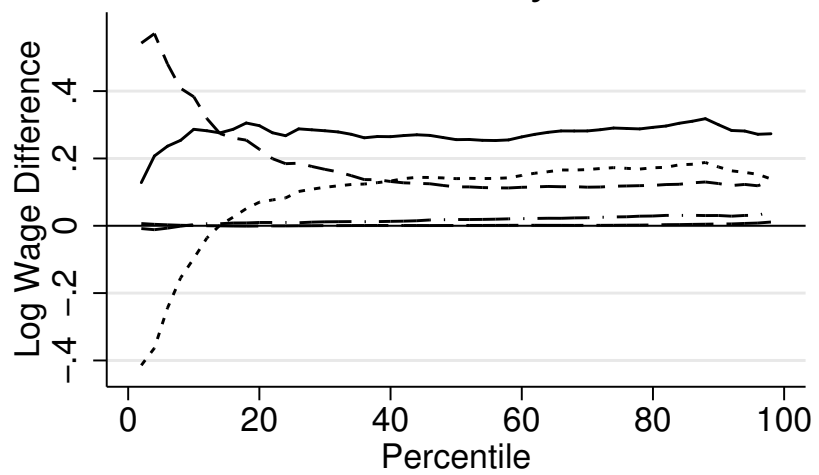

Australia

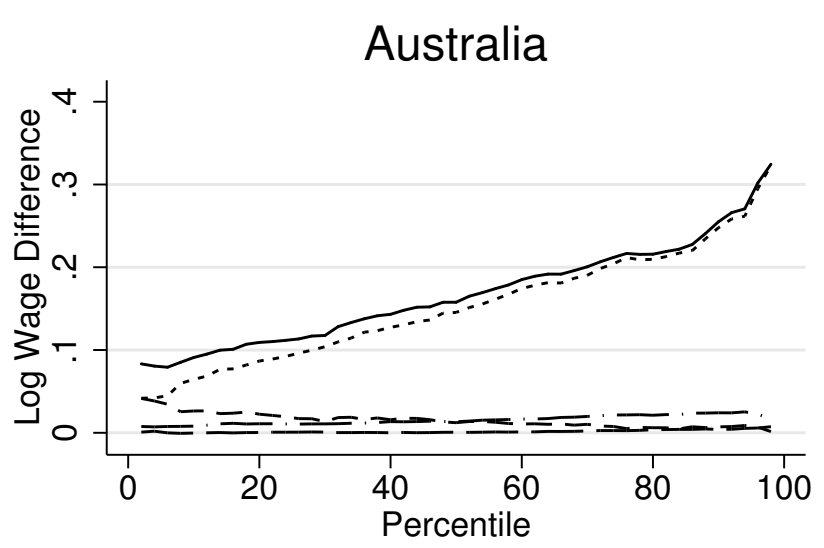

United Kingdom

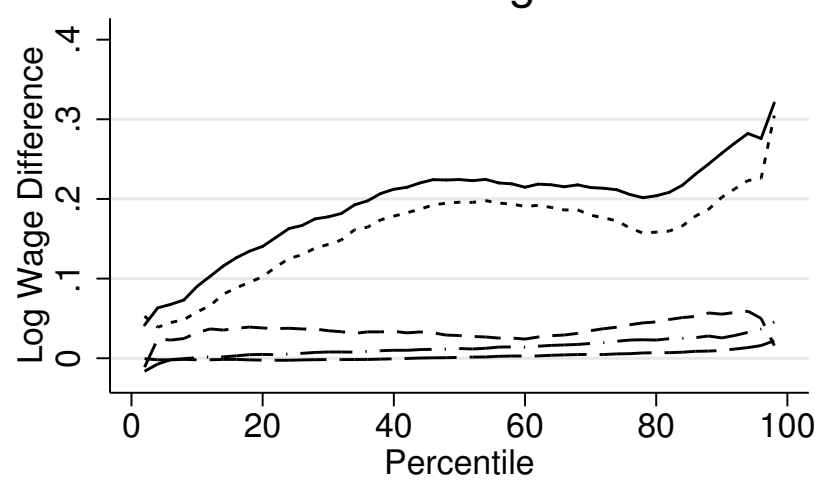

Percentile

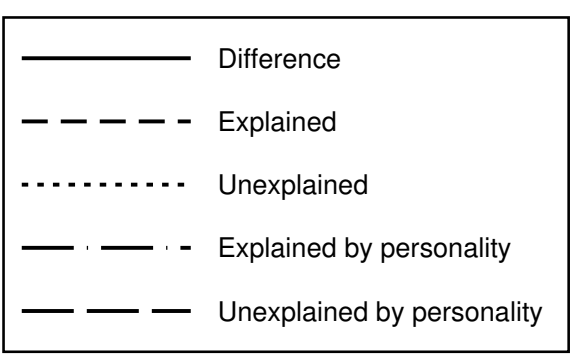

Sources: SOEP v32 1991-2015; UKHLS 2009-2015; HILDA 2001-2015; own calculations.

Figure 1: Decomposition results for the main analysis including controls without controlling for industry and occupation. The graphs correspond to the results in Table 2 . 


\section{Germany}

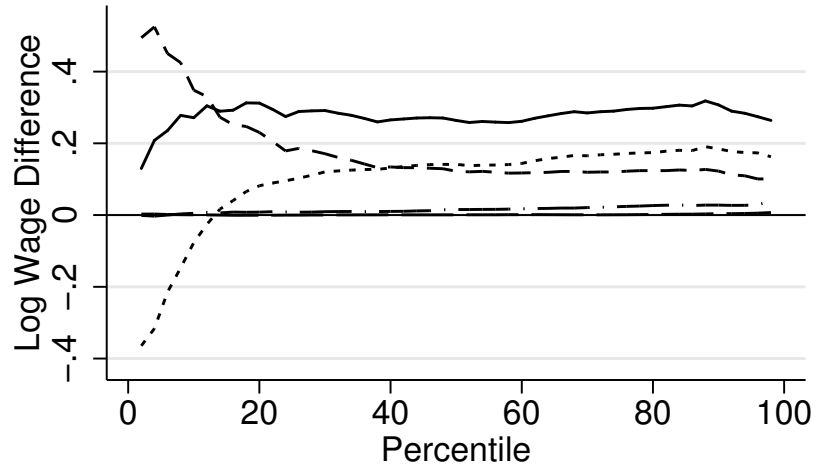

Australia

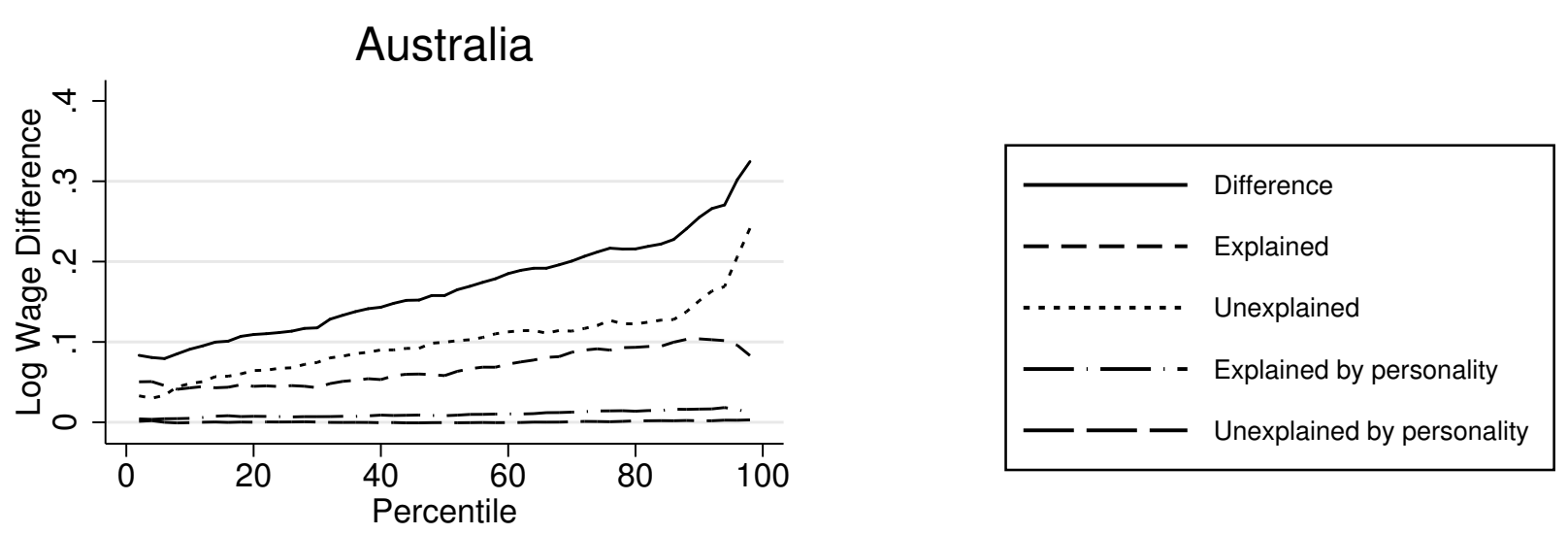

United Kingdom

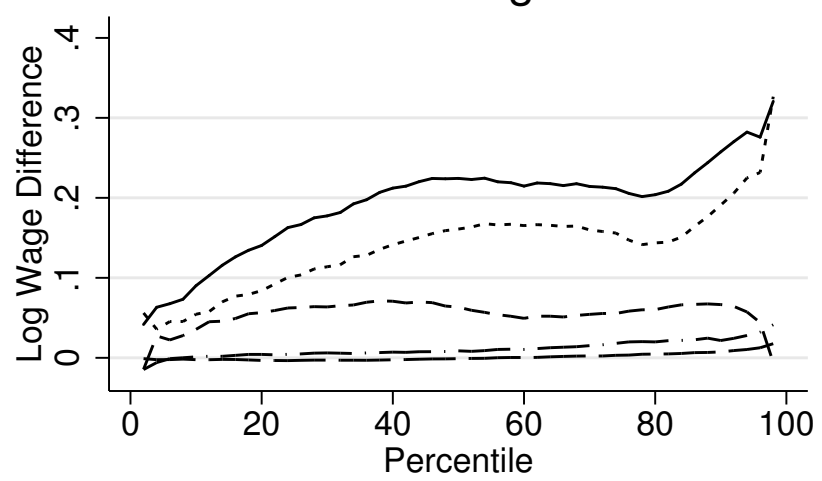

Percentile

Sources: SOEP v32 1991-2015; UKHLS 2009-2015; HILDA 2001-2015; own calculations.

Figure 2: Decomposition results for the main analysis including controls for industry and occupation. The graphs correspond to the results in Table 3. 

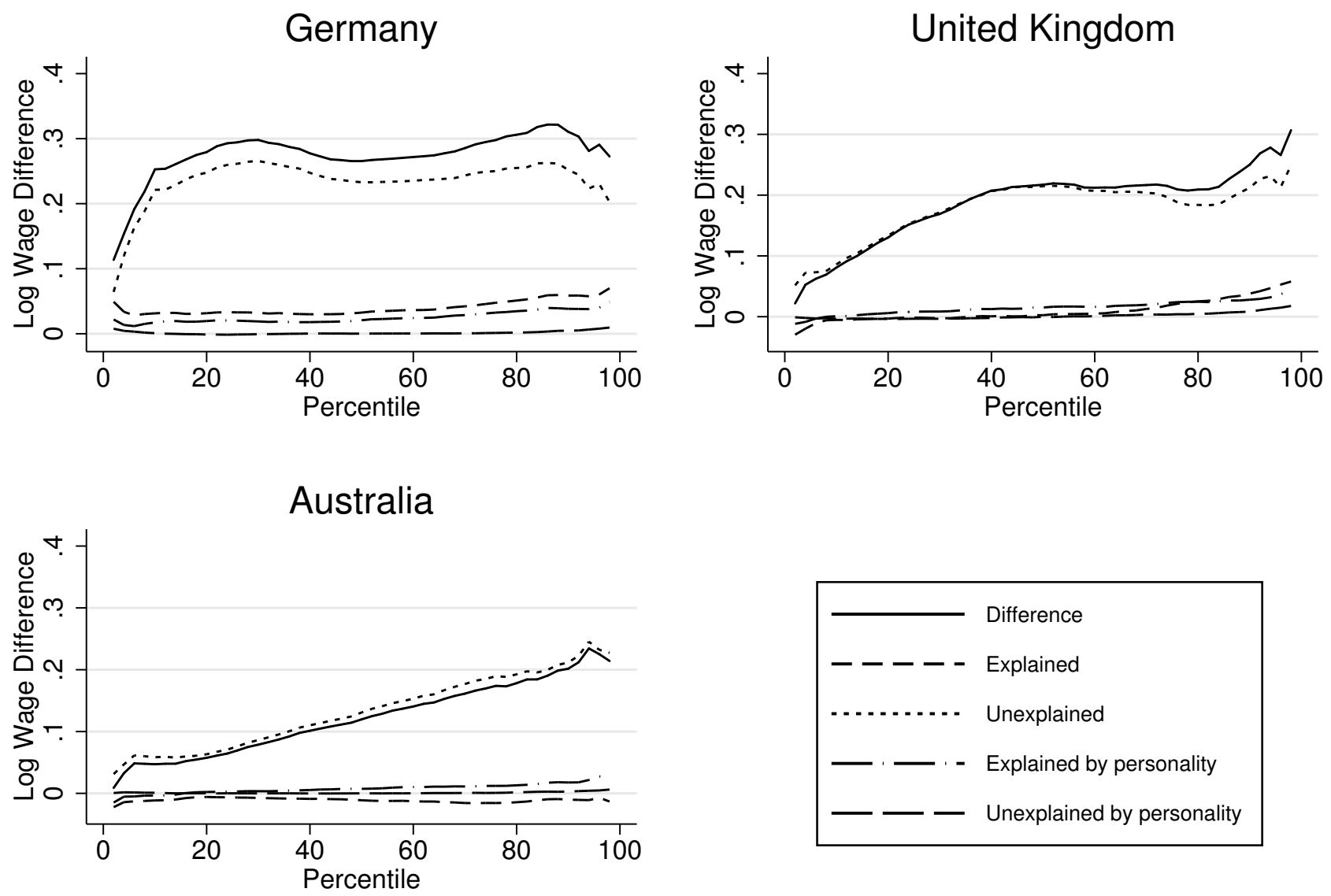

Sources: SOEP v32 1991-2015; UKHLS 2009-2015; HILDA 2001-2015; own calculations.

Figure 3: Decomposition results for with imputed wages with a reduced set of controls. The graphs correspond to the results in Table 4. 

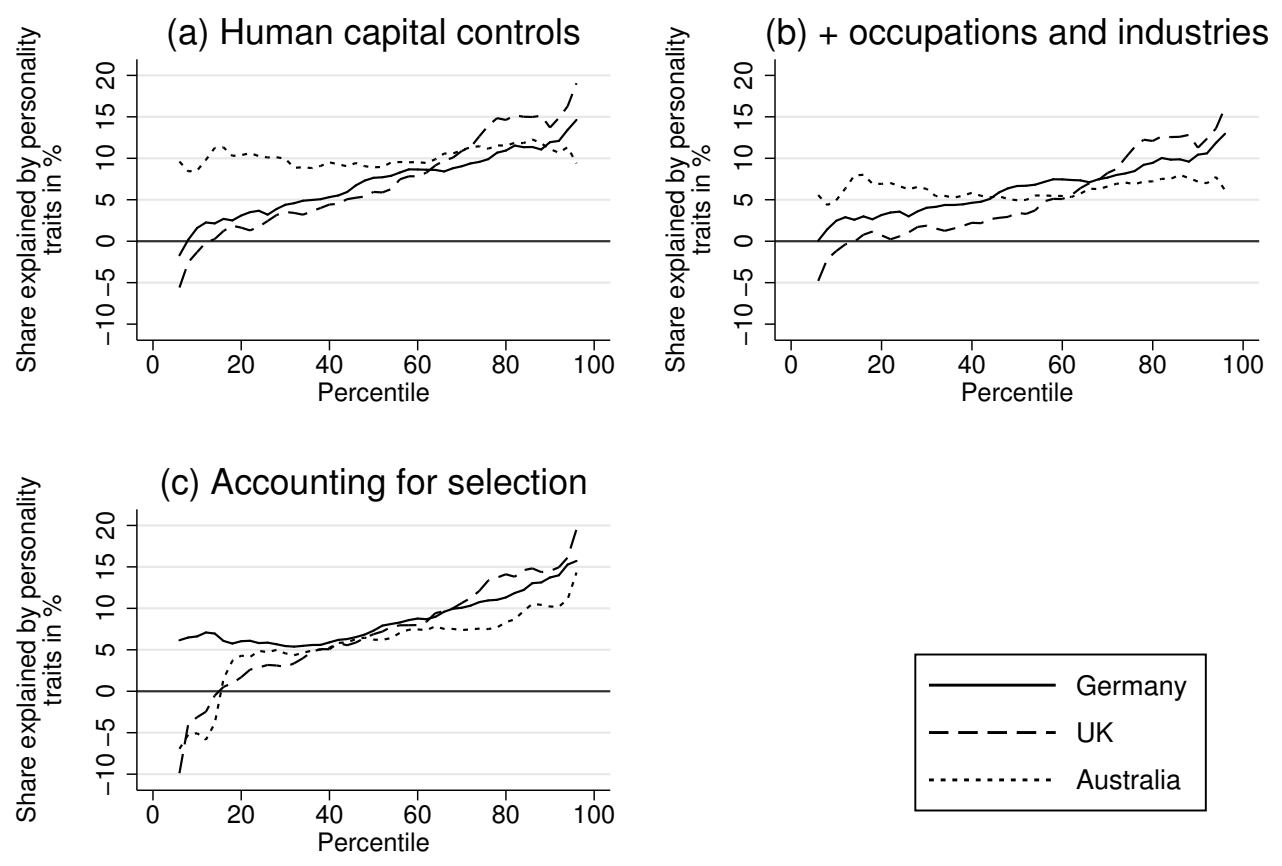

Sources: SOEP v32 1991-2015; UKHLS 2009-2015; HILDA 2001-2015; own calculations.

Figure 4: The relative share of wage gaps explained by personality traits. 


\section{Appendix}

Table A1: Summary statistics for the SOEP

\begin{tabular}{lrr}
\hline Variable & Mean & Std. Dev. \\
\hline Hourly wages & 16.026 & 12.310 \\
Female (dummy) & 0.472 & 0.499 \\
Age & 42.494 & 11.164 \\
Years of schooling & 12.586 & 2.726 \\
Full-time employed (dummy) & 0.736 & 0.441 \\
Married (dummy) & 0.633 & 0.482 \\
Child aged younger or 16 in household (dummy) & 0.389 & 0.488 \\
East Germany (dummy) & 0.228 & 0.420 \\
Establishment size: $\leq 10$ employees & 0.143 & 0.350 \\
Establishment size: $11-100$ employees & 0.295 & 0.456 \\
Establishment size: $101-200$ employees & 0.075 & 0.264 \\
Establishment size: $201-2000$ employees & 0.234 & 0.423 \\
Establishment size: $\geq 2001$ employees & 0.253 & 0.435 \\
\hline
\end{tabular}

Notes: Based on 152,777 observations. ISCO (2-digit) and NACE (top groups) are not shown but included in the data. Source: SOEP v32 19912015 . 
Table A2: Summary statistics for the UKHLS

\begin{tabular}{lcc}
\hline Variable & Mean & Std. Dev. \\
\hline Hourly wages & 15.003 & 37.198 \\
Female (dummy) & 0.576 & 0.494 \\
Age & 40.67 & 11.491 \\
Full-time employed (dummy) & 0.755 & 0.43 \\
Married (dummy) & 0.101 & 0.301 \\
Child aged younger 16 in household (dummy) & 0.402 & 0.49 \\
Establishment size: $\leq$ 24 employees & 0.299 & 0.458 \\
Establishment size: 25-100 employees & 0.263 & 0.44 \\
Establishment size: more than 100 employees & 0.437 & 0.496 \\
Education: Higher degree & 0.154 & 0.361 \\
Education: 1st degree or equivalent & 0.223 & 0.416 \\
Education: Diploma in higher education & 0.097 & 0.296 \\
Education: Teaching qual not pgce & 0.016 & 0.126 \\
Education: Nursing/other med qual & 0.029 & 0.168 \\
Education: Other higher degree & 0.002 & 0.043 \\
Education: A level & 0.107 & 0.309 \\
Education: Welsh baccalaureate & 0 & 0.012 \\
Education: I'nationl baccalaureate & 0.001 & 0.029 \\
Education: AS level & 0.013 & 0.114 \\
Education: Highers (scot) & 0.015 & 0.12 \\
Education: Cert 6th year studies & 0.004 & 0.061 \\
Education: GCSE/O level & 0.257 & 0.437 \\
Education: CSE & 0.056 & 0.231 \\
Education: Standard/o/lower & 0.015 & 0.12 \\
Education: Other school cert & 0.012 & 0.107 \\
\hline
\end{tabular}

Notes: Based on 68,614 observations. ISCO (2-digit) and SIC (top groups) are not shown but included in the data. Source: UKHLS 20092015. 
Table A3: Summary statistics for the HILDA

\begin{tabular}{lcc}
\hline Variable & Mean & Std. Dev. \\
\hline Hourly wages & 28.859 & 15.587 \\
Female (dummy) & 0.482 & 0.5 \\
Age & 40.007 & 11.625 \\
Child aged younger 15 in household (dummy) & 0.337 & 0.473 \\
Married (dummy) & 0.711 & 0.453 \\
Establishment size: Less than 20 & 0.035 & 0.185 \\
Establishment size: 20 to 99 & 0.102 & 0.302 \\
Establishment size: 100 to 499 & 0.195 & 0.397 \\
Establishment size: 500 to 999 & 0.087 & 0.282 \\
Establishment size: 1000 to 4999 & 0.181 & 0.385 \\
Establishment size: 5000 to 19,999 & 0.173 & 0.378 \\
Establishment size: 20,000 or more & 0.227 & 0.419 \\
Education: Postgrad - masters or doctorate & 0.065 & 0.247 \\
Education: Grad diploma, grad certificate & 0.082 & 0.275 \\
Education: Bachelor or honours & 0.197 & 0.398 \\
Education: Adv diploma, diploma & 0.109 & 0.312 \\
Education: Cert III or IV & 0.223 & 0.416 \\
Education: Year 12 & 0.154 & 0.361 \\
Education: Year 11 and below & 0.169 & 0.374 \\
Full-time employed (dummy) & 0.756 & 0.429 \\
\hline
\end{tabular}

Notes: Based on 49,514 observations. ISCO (2-digit) and ANZSIC06 (top groups) are not shown but included in the data. Source: HILDA 2001-2015. 
Table A4: Results of UQR \& least square regressions by gender (SOEP)

\begin{tabular}{|c|c|c|c|c|c|c|c|c|}
\hline & \multicolumn{4}{|c|}{ Females $(\mathrm{N}=72,181)$} & \multicolumn{4}{|c|}{ Males $(\mathrm{N}=80,596)$} \\
\hline & OLS & $\begin{array}{c}10^{t h} \\
\text { Percentile }\end{array}$ & $\begin{array}{c}50^{t h} \\
\text { Percentile }\end{array}$ & $\begin{array}{c}90^{t h} \\
\text { Percentile }\end{array}$ & OLS & $\begin{array}{c}10^{t h} \\
\text { Percentile }\end{array}$ & $\begin{array}{c}50^{t h} \\
\text { Percentile }\end{array}$ & $\begin{array}{c}90^{t h} \\
\text { Percentile }\end{array}$ \\
\hline Extraversion & $\begin{array}{c}-0.001 \\
(0.004)\end{array}$ & $\begin{array}{c}-0.007 \\
(0.010)\end{array}$ & $\begin{array}{c}-0.003 \\
(0.004)\end{array}$ & $\begin{array}{c}0.002 \\
(0.006)\end{array}$ & $\begin{array}{c}-0.001 \\
(0.004)\end{array}$ & $\begin{array}{c}-0.009 \\
(0.006)\end{array}$ & $\begin{array}{c}-0.002 \\
(0.004)\end{array}$ & $\begin{array}{c}0.003 \\
(0.009)\end{array}$ \\
\hline Agreeableness & $\begin{array}{c}-0.015^{* * *} \\
(0.004)\end{array}$ & $\begin{array}{l}0.007 \\
(0.011)\end{array}$ & $\begin{array}{c}-0.019^{* * *} \\
(0.004)\end{array}$ & $\begin{array}{c}-0.026^{* * *} \\
(0.006)\end{array}$ & $\begin{array}{c}-0.026^{* * *} \\
(0.003)\end{array}$ & $\begin{array}{c}-0.023^{* * *} \\
(0.006)\end{array}$ & $\begin{array}{c}-0.024^{* * *} \\
(0.004)\end{array}$ & $\begin{array}{c}-0.036^{* * *} \\
(0.008)\end{array}$ \\
\hline Conscientiousness & $\begin{array}{c}0.008^{*} \\
(0.004)\end{array}$ & $\begin{array}{c}0.012 \\
(0.010)\end{array}$ & $\begin{array}{c}0.005 \\
(0.004)\end{array}$ & $\begin{array}{c}0.008 \\
(0.006)\end{array}$ & $\begin{array}{c}-0.002 \\
(0.003)\end{array}$ & $\begin{array}{c}-0.003 \\
(0.006)\end{array}$ & $\begin{array}{c}-0.005 \\
(0.004)\end{array}$ & $\begin{array}{c}0.010 \\
(0.009)\end{array}$ \\
\hline Neuroticism & $\begin{array}{r}-0.006^{+} \\
(0.003)\end{array}$ & $\begin{array}{l}0.000 \\
(0.009)\end{array}$ & $\begin{array}{c}-0.006 \\
(0.004)\end{array}$ & $\begin{array}{r}-0.012^{*} \\
(0.006)\end{array}$ & $\begin{array}{c}-0.014^{* * *} \\
(0.004)\end{array}$ & $\begin{array}{r}-0.013^{*} \\
(0.006)\end{array}$ & $\begin{array}{c}-0.011^{* *} \\
(0.004)\end{array}$ & $\begin{array}{c}-0.022^{* *} \\
(0.009)\end{array}$ \\
\hline Openness & $\begin{array}{c}-0.003 \\
(0.004)\end{array}$ & $\begin{array}{r}-0.019^{+} \\
(0.010)\end{array}$ & $\begin{array}{c}0.001 \\
(0.004)\end{array}$ & $\begin{array}{c}-0.007 \\
(0.006)\end{array}$ & $\begin{array}{c}0.007^{+} \\
(0.004)\end{array}$ & $\begin{array}{c}0.010 \\
(0.006)\end{array}$ & $\begin{array}{c}0.003 \\
(0.004)\end{array}$ & $\begin{array}{c}0.006 \\
(0.009)\end{array}$ \\
\hline Locus of Control & $\begin{array}{c}-0.030^{* * *} \\
(0.004)\end{array}$ & $\begin{array}{c}-0.046^{* * *} \\
(0.011)\end{array}$ & $\begin{array}{c}-0.019^{* * * *} \\
(0.004)\end{array}$ & $\begin{array}{c}-0.027^{* * *} \\
(0.006)\end{array}$ & $\begin{array}{c}-0.042^{* * *} \\
(0.004)\end{array}$ & $\begin{array}{c}-0.032^{* * *} \\
(0.007)\end{array}$ & $\begin{array}{c}-0.028^{* * *} \\
(0.004)\end{array}$ & $\begin{array}{c}-0.057^{* * *} \\
(0.008)\end{array}$ \\
\hline Positive reciprocity & $\begin{array}{c}0.003 \\
(0.004)\end{array}$ & $\begin{array}{c}0.002 \\
(0.010)\end{array}$ & $\begin{array}{c}0.005 \\
(0.004)\end{array}$ & $\begin{array}{c}0.006 \\
(0.006)\end{array}$ & $\begin{array}{l}0.015^{* * *} \\
(0.004)\end{array}$ & $\begin{array}{l}0.023^{* * *} \\
(0.007)\end{array}$ & $\begin{array}{c}0.008^{+} \\
(0.004)\end{array}$ & $\begin{array}{c}0.025^{* *} \\
(0.009)\end{array}$ \\
\hline Negative reciprocity & $\begin{array}{c}0.001 \\
(0.004)\end{array}$ & $\begin{array}{l}0.006 \\
(0.011)\end{array}$ & $\begin{array}{l}0.000 \\
(0.004)\end{array}$ & $\begin{array}{c}0.009^{+} \\
(0.005)\end{array}$ & $\begin{array}{l}0.000 \\
(0.003)\end{array}$ & $\begin{array}{c}-0.008 \\
(0.006)\end{array}$ & $\begin{array}{c}0.002 \\
(0.004)\end{array}$ & $\begin{array}{c}-0.001 \\
(0.008)\end{array}$ \\
\hline Risk taking & $\begin{array}{c}-0.004 \\
(0.003)\end{array}$ & $\begin{array}{c}-0.025^{* *} \\
(0.009)\end{array}$ & $\begin{array}{c}0.000 \\
(0.003)\end{array}$ & $\begin{array}{c}0.007 \\
(0.005)\end{array}$ & $\begin{array}{l}0.013^{* * *} \\
(0.003)\end{array}$ & $\begin{array}{c}-0.007 \\
(0.005)\end{array}$ & $\begin{array}{l}0.012^{* * *} \\
(0.003)\end{array}$ & $\begin{array}{l}0.030^{* * *} \\
(0.007)\end{array}$ \\
\hline$R^{2}$ & 0.513 & 0.235 & 0.401 & 0.182 & 0.598 & 0.366 & 0.431 & 0.288 \\
\hline
\end{tabular}

Notes: Cluster-robust standard errors are displayed in parentheses. The dependent variable is the natural logarithm of the hourly wage. Significance levels: ${ }^{+} p<0.10,{ }^{*} p<0.05,{ }^{* *} p<0.01,{ }^{* * *} p<0.001$. Source: SOEP v32 1991-2015.

Table A5: Results of UQR \& least square regressions by gender (UKHLS)

\begin{tabular}{|c|c|c|c|c|c|c|c|c|}
\hline & \multicolumn{4}{|c|}{ Females $(\mathrm{N}=39,549)$} & \multicolumn{4}{|c|}{ Males (N=29,065) } \\
\hline & OLS & $\begin{array}{c}10^{t h} \\
\text { Percentile }\end{array}$ & $\begin{array}{c}50^{t h} \\
\text { Percentile }\end{array}$ & $\begin{array}{c}90^{t h} \\
\text { Percentile }\end{array}$ & OLS & $\begin{array}{c}10^{\text {th }} \\
\text { Percentile }\end{array}$ & $\begin{array}{c}50^{t h} \\
\text { Percentile }\end{array}$ & $\begin{array}{c}90^{\text {th }} \\
\text { Percentile }\end{array}$ \\
\hline Extraversion & $\begin{array}{l}0.020^{* * *} \\
(0.005)\end{array}$ & $\begin{array}{l}0.006 \\
(0.005)\end{array}$ & $\begin{array}{c}0.020^{* *} \\
(0.006)\end{array}$ & $\begin{array}{c}0.025^{* *} \\
(0.008)\end{array}$ & $\begin{array}{c}-0.001 \\
(0.007)\end{array}$ & $\begin{array}{c}0.004 \\
(0.005)\end{array}$ & $\begin{array}{c}0.012 \\
(0.008)\end{array}$ & $\begin{array}{c}-0.019 \\
(0.014)\end{array}$ \\
\hline Agreeableness & $\begin{array}{c}-0.031^{* * *} \\
(0.005)\end{array}$ & $\begin{array}{c}-0.009 \\
(0.006)\end{array}$ & $\begin{array}{c}-0.032^{* * * *} \\
(0.007)\end{array}$ & $\begin{array}{c}-0.056^{* * *} \\
(0.009)\end{array}$ & $\begin{array}{c}-0.026^{* * *} \\
(0.006)\end{array}$ & $\begin{array}{c}-0.006 \\
(0.005)\end{array}$ & $\begin{array}{c}-0.020^{* *} \\
(0.007)\end{array}$ & $\begin{array}{c}-0.042^{* * *} \\
(0.013)\end{array}$ \\
\hline Conscientiousness & $\begin{array}{c}0.014^{* *} \\
(0.005)\end{array}$ & $\begin{array}{c}0.018^{* *} \\
(0.006)\end{array}$ & $\begin{array}{c}0.016^{*} \\
(0.007)\end{array}$ & $\begin{array}{c}0.010 \\
(0.008)\end{array}$ & $\begin{array}{l}0.026^{* * *} \\
(0.007)\end{array}$ & $\begin{array}{c}0.015^{* *} \\
(0.005)\end{array}$ & $\begin{array}{c}0.019^{*} \\
(0.008)\end{array}$ & $\begin{array}{c}0.043^{* *} \\
(0.014)\end{array}$ \\
\hline Neuroticism & $\begin{array}{c}-0.026^{* * *} \\
(0.005)\end{array}$ & $\begin{array}{c}-0.018^{* * *} \\
(0.005)\end{array}$ & $\begin{array}{c}-0.025^{* * *} \\
(0.006)\end{array}$ & $\begin{array}{c}-0.024^{* *} \\
(0.008)\end{array}$ & $\begin{array}{c}-0.040^{* * *} \\
(0.006)\end{array}$ & $\begin{array}{c}0.000 \\
(0.005)\end{array}$ & $\begin{array}{c}-0.027^{* * *} \\
(0.008)\end{array}$ & $\begin{array}{c}-0.068^{* * *} \\
(0.013)\end{array}$ \\
\hline Openness & $\begin{array}{c}0.001 \\
(0.005)\end{array}$ & $\begin{array}{r}-0.010^{+} \\
(0.006)\end{array}$ & $\begin{array}{c}0.005 \\
(0.007)\end{array}$ & $\begin{array}{r}0.015^{+} \\
(0.008)\end{array}$ & $\begin{array}{r}0.012^{+} \\
(0.007)\end{array}$ & $\begin{array}{c}-0.002 \\
(0.006)\end{array}$ & $\begin{array}{r}0.020^{*} \\
(0.009)\end{array}$ & $\begin{array}{c}0.029^{*} \\
(0.015)\end{array}$ \\
\hline$R^{2}$ & 0.254 & 0.114 & 0.254 & 0.072 & 0.257 & 0.113 & 0.232 & 0.129 \\
\hline
\end{tabular}

Notes: Cluster-robust standard errors are displayed in parentheses. The dependent variable is the natural logarithm of the hourly wage. Significance levels: ${ }^{+} p<0.10,{ }^{*} p<0.05,{ }^{* *} p<0.01,{ }^{* * *} p<0.001$. Source: UKHLS 2009-2015. 
Table A6: Results of UQR \& least square regressions by gender (HILDA)

\begin{tabular}{|c|c|c|c|c|c|c|c|c|}
\hline & \multicolumn{4}{|c|}{ Females $(\mathrm{N}=23,844)$} & \multicolumn{4}{|c|}{ Males $(\mathrm{N}=25,670)$} \\
\hline & OLS & $\begin{array}{c}10^{\text {th }} \\
\text { Percentile }\end{array}$ & $\begin{array}{c}50^{t h} \\
\text { Percentile }\end{array}$ & $\begin{array}{c}90^{t h} \\
\text { Percentile }\end{array}$ & OLS & $\begin{array}{c}10^{t h} \\
\text { Percentile }\end{array}$ & $\begin{array}{c}50^{t h} \\
\text { Percentile }\end{array}$ & $\begin{array}{c}90^{t h} \\
\text { Percentile }\end{array}$ \\
\hline Extraversion & $\begin{array}{c}0.002 \\
(0.004)\end{array}$ & $\begin{array}{c}0.001 \\
(0.006)\end{array}$ & $\begin{array}{c}0.002 \\
(0.005)\end{array}$ & $\begin{array}{c}0.003 \\
(0.007)\end{array}$ & $\begin{array}{c}-0.003 \\
(0.006)\end{array}$ & $\begin{array}{r}-0.011^{*} \\
(0.006)\end{array}$ & $\begin{array}{c}-0.007 \\
(0.006)\end{array}$ & $\begin{array}{c}0.005 \\
(0.013)\end{array}$ \\
\hline Agreeableness & $\begin{array}{c}-0.031^{* * *} \\
(0.005)\end{array}$ & $\begin{array}{c}-0.024^{* *} \\
(0.008)\end{array}$ & $\begin{array}{c}-0.026^{* * *} \\
(0.006)\end{array}$ & $\begin{array}{c}-0.045^{* * *} \\
(0.008)\end{array}$ & $\begin{array}{c}-0.042^{* * *} \\
(0.006)\end{array}$ & $\begin{array}{r}-0.013^{+} \\
(0.007)\end{array}$ & $\begin{array}{c}-0.035^{* * *} \\
(0.006)\end{array}$ & $\begin{array}{c}-0.073^{* * *} \\
(0.013)\end{array}$ \\
\hline Conscientiousness & $\begin{array}{l}0.022^{* * *} \\
(0.004)\end{array}$ & $\begin{array}{r}0.016^{*} \\
(0.006)\end{array}$ & $\begin{array}{l}0.018^{* * *} \\
(0.005)\end{array}$ & $\begin{array}{l}0.026^{* * *} \\
(0.007)\end{array}$ & $\begin{array}{l}0.022^{* * * *} \\
(0.006)\end{array}$ & $\begin{array}{l}0.007 \\
(0.006)\end{array}$ & $\begin{array}{c}0.018^{* *} \\
(0.006)\end{array}$ & $\begin{array}{c}0.034^{* *} \\
(0.012)\end{array}$ \\
\hline Neuroticism & $\begin{array}{c}0.006 \\
(0.004)\end{array}$ & $\begin{array}{c}0.002 \\
(0.007)\end{array}$ & $\begin{array}{c}0.002 \\
(0.005)\end{array}$ & $\begin{array}{c}0.009 \\
(0.007)\end{array}$ & $\begin{array}{c}0.005 \\
(0.005)\end{array}$ & $\begin{array}{c}0.002 \\
(0.006)\end{array}$ & $\begin{array}{c}0.003 \\
(0.005)\end{array}$ & $\begin{array}{c}0.012 \\
(0.012)\end{array}$ \\
\hline Openness & $\begin{array}{c}0.001 \\
(0.004)\end{array}$ & $\begin{array}{r}-0.014^{*} \\
(0.007)\end{array}$ & $\begin{array}{l}0.000 \\
(0.005)\end{array}$ & $\begin{array}{c}0.012^{+} \\
(0.007)\end{array}$ & $\begin{array}{c}0.009 \\
(0.006)\end{array}$ & $\begin{array}{c}0.001 \\
(0.006)\end{array}$ & $\begin{array}{l}0.006 \\
(0.006)\end{array}$ & $\begin{array}{l}0.006 \\
(0.013)\end{array}$ \\
\hline Locus of Control & $\begin{array}{c}-0.036^{* * *} \\
(0.004)\end{array}$ & $\begin{array}{c}-0.029^{* * *} \\
(0.007)\end{array}$ & $\begin{array}{c}-0.043^{* * *} \\
(0.005)\end{array}$ & $\begin{array}{c}-0.038^{* * *} \\
(0.007)\end{array}$ & $\begin{array}{c}-0.060^{* * *} \\
(0.006)\end{array}$ & $\begin{array}{c}-0.033^{* * *} \\
(0.007)\end{array}$ & $\begin{array}{c}-0.055^{* * *} \\
(0.006)\end{array}$ & $\begin{array}{c}-0.080^{* * * *} \\
(0.011)\end{array}$ \\
\hline$R^{2}$ & 0.376 & 0.150 & 0.298 & 0.092 & 0.375 & 0.133 & 0.284 & 0.158 \\
\hline
\end{tabular}

Notes: Cluster-robust standard errors are displayed in parentheses. The dependent variable is the natural logarithm of the hourly wage. Significance levels: ${ }^{+} p<0.10,{ }^{*} p<0.05,{ }^{* *} p<0.01,{ }^{* * *} p<0.001$. Source: HILDA 2001-2015. 
Table A7: Results of the UQR \& least square regressions, pooled samples

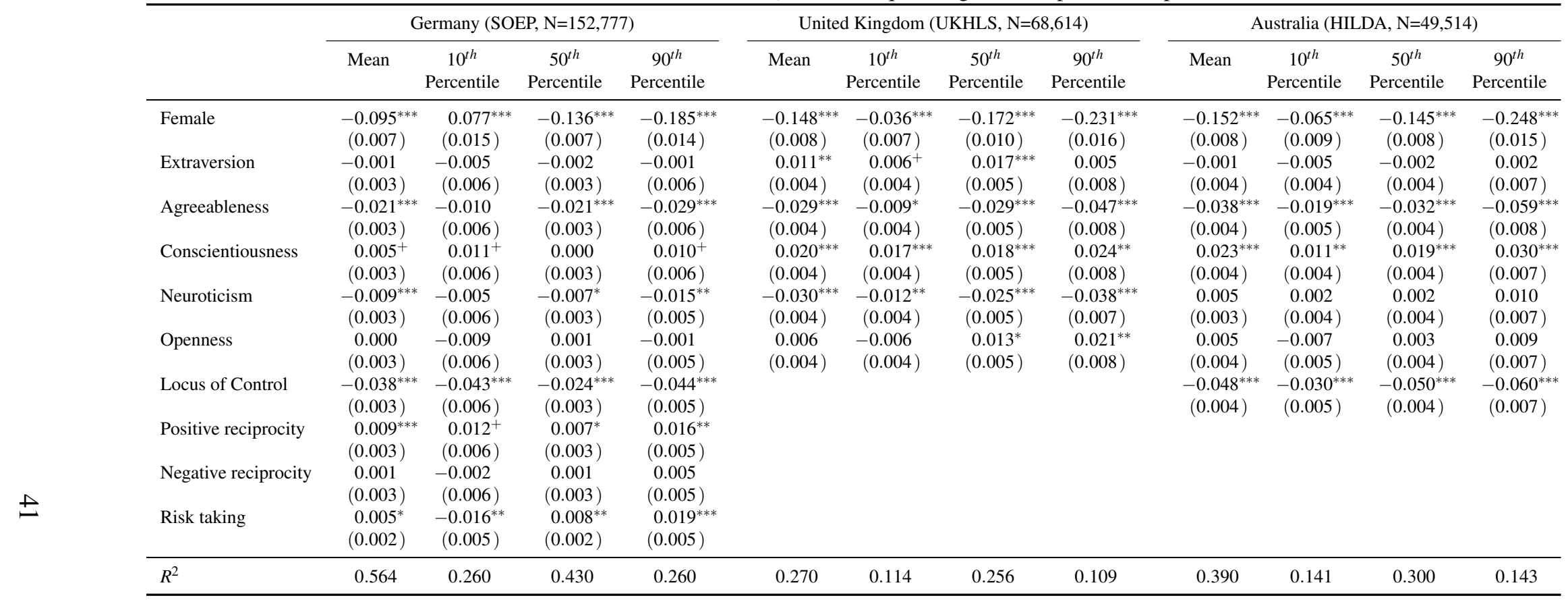

Notes: Cluster-robust standard errors in parentheses. The dependent variable is the natural logarithm of the hourly wage. Every estimation accounts for the full set of control variables. Significance levels: ${ }^{+} p<0.10,{ }^{*} p<0.05,{ }^{* *} p<0.01,{ }^{* * *} p<0.001$. Sources: SOEP v32 1991-2015, UKHLS 2009-2015, HILDA 2001-2015. 